\title{
Tetrodotoxin-Sensitive Sodium Channels Mediate Action Potential Firing and Excitability in Menthol-Sensitive Vglut3-Lineage Sensory Neurons
}

\author{
Theanne N. Griffith, ${ }^{1,4}$ Trevor A. Docter, ${ }^{2}$ and Ellen A. Lumpkin ${ }^{1,3,4}$ \\ ${ }^{1}$ Department of Physiology and Cellular Biophysics, ${ }^{2}$ Undergraduate Program in Neuroscience and Behavior, ${ }^{3}$ Department of Dermatology, Columbia \\ University, New York, New York, 10032, and ${ }^{4}$ Neurobiology Course, Marine Biological Laboratory, Woods Hole, Massachusetts 02543
}

Small-diameter vesicular glutamate transporter 3-lineage (Vglut3 ${ }^{\text {lineage }}$ ) dorsal root ganglion (DRG) neurons play an important role in mechanosensation and thermal hypersensitivity; however, little is known about their intrinsic electrical properties. We therefore set out to investigate mechanisms of excitability within this population. Calcium microfluorimetry analysis of male and female mouse DRG neurons demonstrated that the cooling compound menthol selectively activates a subset of Vglut $3{ }^{\text {lineage }}$ neurons. Whole-cell recordings showed that small-diameter Vglut $3{ }^{\text {lineage }}$ DRG neurons fire menthol-evoked action potentials and exhibited robust, transient receptor potential melastatin 8 (TRPM8)-dependent discharges at room temperature. This heightened excitability was confirmed by currentclamp and action potential phase-plot analyses, which showed menthol-sensitive Vglut $3{ }^{\text {lineage }}$ neurons to have more depolarized membrane potentials, lower firing thresholds, and higher evoked firing frequencies compared with menthol-insensitive Vglut $3{ }^{\text {lineage }}$ neurons. A biophysical analysis revealed voltage-gated sodium channel $\left(\mathrm{Na}_{\mathrm{V}}\right)$ currents in menthol-sensitive Vglut 3 lineage neurons were resistant to entry into slow inactivation compared with menthol-insensitive neurons. Multiplex in situ hybridization showed similar distributions of tetrodotoxin (TTX)-sensitive $\mathrm{Na}_{\mathrm{V}}$ transcripts between TRPM8-positive and -negative Vglut $3{ }^{\text {lineage }}$ neurons; however, $\mathrm{Na}_{\mathrm{V}} 1.8$ transcripts, which encode TTX-resistant channels, were more prevalent in TRPM8-negative neurons. Conversely, pharmacological analyses identified distinct functional contributions of $\mathrm{Na}_{\mathrm{V}}$ subunits, with $\mathrm{Na}_{\mathrm{V}} 1.1$ driving firing in menthol-sensitive neurons, whereas other small-diameter Vglut $3{ }^{\text {lineage }}$ neurons rely primarily on TTX-resistant $\mathrm{Na}_{\mathrm{V}}$ channels. Additionally, when $\mathrm{Na}_{\mathrm{V}} 1.1$ channels were blocked, the remaining $\mathrm{Na}_{\mathrm{V}}$ current readily entered into slow inactivation in menthol-sensitive Vglut $3{ }^{\text {lineage }}$ neurons. Thus, these data demonstrate that TTX-sensitive $\mathrm{Na}_{\mathrm{V}}$ s drive action potential firing in menthol-sensitive sensory neurons and contribute to their heightened excitability.

Key words: action potential; dorsal root ganglion; excitability; sensory neuron; sodium channel

Significance Statement

Somatosensory neurons encode various sensory modalities including thermoreception, mechanoreception, nociception, and itch. This report identifies a previously unknown requirement for tetrodotoxin-sensitive sodium channels in action potential firing in a discrete subpopulation of small-diameter sensory neurons that are activated by the cooling agent menthol. Together, our results provide a mechanistic understanding of factors that control intrinsic excitability in functionally distinct subsets of peripheral neurons. Furthermore, as menthol has been used for centuries as an analgesic and anti-pruritic, these findings support the viability of $\mathrm{Na}_{\mathrm{v}} 1.1$ as a therapeutic target for sensory disorders.

\section{Introduction}

Small-diameter dorsal root ganglion (DRG) neurons are sensory neurons that encode a diverse array of somatic sensations, in-

Received Nov. 12, 2018; revised June 4, 2019; accepted July 3, 2019.

Author contributions: T.N.G. and E.A.L. designed research; T.N.G., T.A.D., and E.A.L. performed research; T.N.G., T.A.D., and E.A.L. analyzed data; T.N.G. and E.A.L. wrote the paper.

This work was supported by NIAMS R01AR051219 (E.A.L.). T.N.G. holds a Postdoctoral Enrichment Program Award from the Burroughs Wellcome Fund and was supported by NHLBI T32HL120826. Core facilities were sup- cluding various forms of pain, thermosensation, itch, and touch (Dubin and Patapoutian, 2010; McGlone and Reilly, 2010; Schepers and Ringkamp, 2010; Bautista et al., 2014; Liljencrantz 
and Olausson, 2014). This functional diversity is encompassed by small-diameter DRG neurons of the vesicular glutamate transporter 3 lineage (Vglut $3^{\text {lineage }}$ ), which comprise $\sim 15 \%$ of DRG neurons (Lou et al., 2013). For example, a subpopulation of Vglut $3{ }^{\text {lineage }}$ neurons are unmyelinated, low threshold mechanoreceptors that encode tactile stimuli (Seal et al., 2009). Furthermore, transient receptor potential melastatin (TRPM8)-expressing Vglut $3^{\text {lineage }}$ neurons are proposed to mediate oxaliplatin-induced cold hypersensitivity (Draxler et al., 2014). The diverse physiological processes in which these neurons have been implicated suggest that they engage distinct transduction mechanisms to encode sensory information. Yet, the molecular determinants involved in transmitting electrical signals in discrete subpopulations of Vglut $3^{\text {lineage }}$ neurons remain poorly understood.

Following membrane depolarization, activation of voltagegated sodium channels $\left(\mathrm{Na}_{\mathrm{V}} \mathrm{s}\right)$ initiate action potentials. In sensory neurons, both action potential shape and discharge frequency transmit important information (Djouhri et al., 1998; Park and Dunlap, 1998; Liu et al., 2017), a concept that is clearly illustrated in small-diameter nociceptors. These neurons predominantly express tetrodotoxin (TTX)-sensitive $\mathrm{Na}_{\mathrm{V}} 1.7$ channels, as well as TTX-resistant $\mathrm{Na}_{\mathrm{V}} 1.8$ and $\mathrm{Na}_{\mathrm{V}} 1.9$ subunits. Many small-diameter, nociceptive DRG neurons exhibit a prominent TTX-resistant sodium current that produces a "shoulder" during action potential repolarization, therefore increasing action potential duration (Ritter and Mendell, 1992; Djouhri et al., 1998; Blair and Bean, 2002). The inactivation kinetics of TTX-resistant sodium currents during this shoulder likely allow for a greater contribution of high-voltage activated calcium channels, which may increase calcium entry and could be particularly relevant to neurotransmitter release at presynaptic terminals (Blair and Bean, 2002). Additionally, the kinetics of slow inactivation of TTXresistant voltage-gated sodium channels in nociceptive neurons controls firing rate adaption in response to sustained depolarization (Blair and Bean, 2003; Choi et al., 2007). Thus, the molecular identity and biophysical properties of $\mathrm{Na}_{\mathrm{V}} \mathrm{s}$ expressed in a given neuron impact action potential firing and sensory coding.

Despite the contributions of small-diameter Vglut 3 lineage neurons to somatosensation, the $\mathrm{Na}_{\mathrm{V}} \mathrm{s}$ that mediate action potential firing in these neurons remain unknown. Such information can provide important insights as to how developmentally related, yet functionally diverse, DRG neurons differentially engage $\mathrm{Na}_{V} s$ to transmit sensory information. Accordingly, we asked whether subpopulations of smalldiameter Vglut ${ }^{\text {lineage }}$ DRG neurons possess measurable differences in intrinsic excitability and, if so, whether such differences reflect the contributions of functionally distinct $\mathrm{Na}_{\mathrm{V}}$ subunits. Here, we show that small-diameter Vglut $3{ }^{\text {lineage }}$ neurons activated by the cooling compound menthol exhibit heightened excitability compared with menthol-insensitive neurons, firing robust trains of TRPM8-dependent action potentials at room temperature. Furthermore, in vitro electrophysiological and pharmacological analyses revealed that unlike nociceptors, TTX-sensitive ion channels, including $\mathrm{Na}_{\mathrm{V}} 1.1$, drive action potential firing and mediate excitability in these neurons.

The authors declare no competing financial interests. Correspondence should be addressed to Ellen A. Lumpkin at ellen.a.lumpkin@gmail.com. https://doi.org/10.1523/JNEUROSCI.2817-18.2019

Copyright $(2019$ the authors

\section{Materials and Methods}

Key resources. Table 1 contains a list of this study's key resources, suppliers, and unique identifying information. RRIDs are provided for mouse strains and antibodies.

Animals. Animal use was conducted according to guidelines from the National Institutes of Health's Guide for the Care and Use of Laboratory Animals and was approved by the Institutional Animal Care and Use Committee of Columbia University Medical Center. Mice were maintained on a $12 \mathrm{~h}$ light/dark cycle, and food and water was provided ad libitum. Slc17a8 ${ }^{\text {iCre }}$ (stock \#018147; Grimes et al., 2011) and Rosa26 $6^{\text {Ail }}$ mice (stock \#007914; Madisen et al., 2010) were obtained from Jackson Laboratories and bred to produce Slc17a $8^{\text {iCre }}$;Rosa2 $6^{\text {Ail4 }}$ mice. Genotyping was performed through Transnetyx. Adult Slc17a ${ }^{i C r e} ;$ Rosa $26^{\text {Ail }}$ mice (4-16 weeks old) of either sex were used for all experiments.

$D R G$ culture preparation. DRGs were harvested from Slc17a8 ${ }^{i C r e}$; Rosa26 $6^{\text {Ail4 }}$ mice and transferred to $\mathrm{Ca}^{2+}$-free, $\mathrm{Mg}^{2+}$-free HBSS (Invitrogen) containing the following (in $\mathrm{mm}$ ): $137.9 \mathrm{NaCl}, 5.3 \mathrm{KCl}, 0.34$ $\mathrm{Na}_{2} \mathrm{HPO}_{4}, 0.44 \mathrm{~K}_{2} \mathrm{HPO}_{4}, 5.6$ glucose, $4.2 \mathrm{NaHCO}_{3}, 0.01 \%$ phenol red. Processes were trimmed to reduce the amount of plated non-neuronal cells. Ganglia were treated with collagenase $(1.5 \mathrm{mg} / \mathrm{ml}$; Type P, SigmaAldrich) in HBSS for $20 \mathrm{~min}$ at $37^{\circ} \mathrm{C}$ followed by $0.05 \%$ Trypsin-EDTA (Invitrogen) for $3 \mathrm{~min}$ with gentle rotation. Trypsin was neutralized with culture media (MEM, with L-glutamine, Phenol Red, without sodium pyruvate) supplemented with $10 \%$ horse serum (heat-inactivated; Invitrogen), $10 \mathrm{U} / \mathrm{ml}$ penicillin, $10 \mu \mathrm{g} / \mathrm{ml}$ streptomycin, MEM vitamin solution (Invitrogen), and B-27 supplement. Serum-containing media was decanted and cells were triturated using a fire-polished Pasteur pipette in a serum-free MEM culture media containing the supplements listed above. Cells were plated on laminin-treated $(0.05 \mathrm{mg} / \mathrm{ml})$ glass coverslips, which had previously been washed in $2 \mathrm{~N} \mathrm{NaOH}$ for at least $4 \mathrm{~h}$, rinsed with $70 \%$ ethanol and UV-sterilized. Cells were then incubated at $37^{\circ} \mathrm{C}$ in $5 \% \mathrm{CO}_{2}$. Cells were used for electrophysiological experiments $16-24 \mathrm{~h}$ after plating.

HEK cell culture and transfection. Stably transfected HEK293 cell lines expressing human $\mathrm{Na}_{\mathrm{V}} 1.1$ (Kahlig et al., 2010), $\mathrm{Na}_{\mathrm{V}} 1.6$ (Dr. Lori Isom, University of Michigan), or HEK293 cells transiently transfected with a cDNA construct containing human $\mathrm{Na}_{\mathrm{V}} 1.7$ (Dr. Manu Ben-Johny, Columbia University) were used. The $\mathrm{Na}_{\mathrm{V}} 1.7$ plasmid was sequenced following transformation and extraction (GENEWIZ, see Mendeley dataset). HEK cells were grown in DMEM (Invitrogen, 11995) containing 10\% FBS (ThermoFisher Scientific A3840101), 1\% penicillinstreptomycin (ThermoFisher Scientific, 15-140-122). Media for HEK cells stably expressing $\mathrm{Na}_{\mathrm{V}} 1.1$ or $\mathrm{Na}_{\mathrm{V}} 1.6$ also contained $400 \mu \mathrm{g} / \mathrm{ml} \mathrm{G418}$ (Fisher Scientific, 10-131-035) to select for transfected cells. A calcium phosphate protocol was used to co-transfect $\mathrm{Na}_{\mathrm{V}} 1.7$ and green fluorescent protein into HEK 293 cells. Briefly, $2 \mathrm{M} \mathrm{CaCl}_{2}, \mathrm{cDNAs}$, and sterile water were mixed together and added dropwise to a $2 \times$ solution of HEPES buffered saline. The final solution was added dropwise to HEK293 cells that were plated the day before on glass coverslips coated with $0.05 \mathrm{mg} / \mathrm{ml}$ laminin. Cells were incubated at $37^{\circ} \mathrm{C}$ in $5 \% \mathrm{CO}_{2}$ with the transfection solution for $3 \mathrm{~h}$, followed by two washes with sterile PBS and addition of new cell culture media. Electrophysiological recordings were performed $24-72 \mathrm{~h}$ post-transfection.

Electrophysiology. Whole-cell voltage-clamp and current-clamp recordings made from small-diameter (capacitance $\leq 25 \mathrm{pF}$ ), TdTomatoexpressing (Vglut $3^{\text {lineage }}$ ) dissociated DRG neurons and HEK cells were performed with patch pipettes pulled from standard borosilicate glass (1B150F-4, World Precision Instruments) with a P-97 puller (Sutter Instruments). For neuronal recordings, patch pipettes had resistances of 3-6 $\mathrm{M} \Omega$ when filled with an internal solution containing the following (in mM): $120 \mathrm{~K}$-methylsulfonate, $10 \mathrm{KCl}, 10 \mathrm{NaCl}, 5 \mathrm{EGTA}, 0.5 \mathrm{CaCl}_{2}, 10$ HEPES, 2.5 MgATP, pH 7.2 with $\mathrm{KOH}$, osmolarity 300 mOsm. For HEK cell recordings, patch pipettes had resistances of 1.5-3 $\mathrm{M} \Omega$ when filled with an internal solution containing the following (in mM): $140 \mathrm{CsF}, 10$ $\mathrm{NaCl}, 2 \mathrm{MgCl}_{2}, 0.1 \mathrm{CaCl}_{2}, 1.1$ EGTA, 10 HEPES, pH 7.2 with $\mathrm{CsOH}$, osmolarity $\sim 310 \mathrm{mOsm}$. Seals and whole-cell configuration were obtained in an external solution containing the following (in $\mathrm{mM}$ ): 145 $\mathrm{NaCl}, 5 \mathrm{KCl}, 10 \mathrm{HEPES}, 10$ glucose, $2 \mathrm{CaCl}_{2}, 2 \mathrm{MgCl}_{2}, \mathrm{pH} 7.3$ with 
Table 1. Key resources, suppliers, and unique identifying information

\begin{tabular}{|c|c|c|}
\hline Reagent or Resource & Source & Identifier \\
\hline \multicolumn{3}{|l|}{ Antibodies } \\
\hline Rabbit polyclonal anti-DsRed & Clontech Laboratories & Catalog \#632496, RRID:AB_10013483 \\
\hline Goat anti-rabbit polyclonal AlexaFluor 594 & ThermoFisher Scientific & Catalog\#A-11037, RRID:AB_2534095 \\
\hline Collagenase type $P$ & Sigma-Aldrich & Catalog \#11249002001 \\
\hline OCT compound & Tissue-Tek & Catalog \#4583 \\
\hline Trypsin-EDTA 0.05\% & Fisher Scientific & Catalog \#25300054 \\
\hline MEM & Fisher Scientific & Catalog \#11098050 \\
\hline Penicillin-streptomycin & Fisher Scientific & Catalog \#15-140-122 \\
\hline MEM vitamin solution & ThermoFisher Scientific & Catalog\#SH3059901 \\
\hline B-27 supplement & Fisher Scientific & Catalog \#17504044 \\
\hline Horse serum, heat inactivated & ThermoFisher Scientific & Catalog \#26050070 \\
\hline Fura-2, AM & ThermoFisher Scientific & Catalog \#F1221 \\
\hline TTX & Abcam & Catalog \#ab120054 \\
\hline AH-TTX & R\&D Systems & Catalog \#6159/100U \\
\hline PF 05089771 & Tocris Bioscience & Catalog \#5931 \\
\hline ICA 121431 & Tocris Bioscience & Catalog \#5066/10 \\
\hline PN3a & Deuis et al. (2017) & \\
\hline \multicolumn{3}{|l|}{ Critical commercial assays } \\
\hline Plasmid Maxi kit & Qiagen & Catalog \#12162 \\
\hline RNAscope Fluorescent Multiplex kit & Advanced Cell Diagnostics & Catalog \#320850 \\
\hline \multicolumn{3}{|l|}{ Deposited data } \\
\hline Source Data (freely available through Mendeley) & This study & http://dx.doi.org/10.17632/bxsvmy2zh3.1 \\
\hline Movie of calcium imaging experiment & This study & http://dx.doi.org/10.17632/bxsvmy2zh3.1 \\
\hline \multicolumn{3}{|l|}{ Experimental Models: Organisms/Strains } \\
\hline Scn9a probe channel 2 & Advanced Cell Diagnostics & Catalog \#313341-C2 \\
\hline Scn10a probe channel 2 & Advanced Cell Diagnostics & Catalog \#426011-C2 \\
\hline \multicolumn{3}{|l|}{ Software and Algorithms } \\
\hline pClamp 10 Software Suite & Molecular Devices & https://www.moleculardevices.com \\
\hline Image J & Schneider et al. (2012) & https://imagej.nih.gov/ij/index.html \\
\hline MATLAB 2017b & MathWorks & https://www.mathworks.com \\
\hline Software, algorithm, custom (MATLAB) & This study & https://github.com/thelumpkinlab/Calcium-Imaging-Analysis-Script \\
\hline MetaMorph v7.50.6 & Molecular Devices & https://www.moleculardevices.com \\
\hline MetaFluor v7.60.3 & Molecular Devices & https://www.moleculardevices.com \\
\hline Prism v7.0b & GraphPad & https://www.graphpad.com \\
\hline
\end{tabular}

$\mathrm{NaOH}$, osmolarity $\sim 320 \mathrm{mOsm}$. Series resistance was compensated by $80 \%$. In experiments with DRG neurons where currents from voltagegated sodium channels were recorded, after the whole-cell configuration was established and neurons were tested for sensitivity to menthol, a modified external solution was applied containing the following (in $\mathrm{mm}$ ): $105 \mathrm{NaCl}, 40$ TEA-Cl, 10 HEPES, $2 \mathrm{BaCl}_{2}, 13$ glucose, $0.03 \mathrm{CdCl}_{2}, \mathrm{pH} 7.3$ with $\mathrm{NaOH}$, osmolarity $\sim 320 \mathrm{mOsm}$. This modified solution was used in HEK cell recordings following seal acquisition in a standard external solution. All solutions used were allowed to warm to ambient temperature before each experiment to ensure all recordings were made at room temperature $\left(20-23^{\circ} \mathrm{C}\right)$. After each experiment, the recording chamber was thoroughly cleaned with Milli-Q water. For experiments using $\mathrm{Na}_{\mathrm{V}}$ inhibitors, drugs were applied to neurons for $1 \mathrm{~min}$ in current-clamp mode in the absence of injected current; therefore, cells were recorded at their intrinsic $V_{\mathrm{m}}$.
Data acquisition and analysis. Currents and voltages were acquired and analyzed using pClamp software v10 (Molecular Devices). Recordings were obtained using an AxoPatch 200b patch-clamp amplifier and a Digidata $1440 \mathrm{~A}$, and filtered at $5 \mathrm{kHz}$ and digitized at $10 \mathrm{kHz}$. Analysis was performed using Clampfit 10 (Molecular Devices). All voltages were corrected for the measured liquid junction potential $(-7 \mathrm{mV})$ between internal and external recording solutions. Phase plots were constructed from the first derivative of the somatic membrane potential (dV/dT) versus the instantaneous somatic membrane potential. Action potential threshold was calculated as the membrane potential at which the phase plot slope reached $10 \mathrm{mV} \mathrm{ms}^{-1}$ (Kress et al., 2008; Yu et al., 2008). Duration at the base was calculated by measuring the duration of the action potential starting at the resting membrane potential $\left(V_{\mathrm{m}}\right)$ and ending when the repolarization phase again passed the initial $V_{m}$. Following determination of menthol sensitivity in gap-free recording mode, 
some cells were not further analyzed using phase plot analysis due to low digital gain during recordings $(n=3)$ or deteriorating cell health $(n=2)$.

Pharmacology. TTX was from Abcam. PF 05089771 and ICA 121431 were from Tocris Bioscience. PN3a was a generous gift from Dr. Irina Vetter (Institute for Molecular Biosciences, University of Queensland). All other chemicals were from Sigma-Aldrich.

Calcium imaging. Dissociated DRG neurons were loaded for $45 \mathrm{~min}$ with $10 \mathrm{~mm}$ Fura-2AM (Invitrogen), supplemented with $0.01 \% \mathrm{w} / \mathrm{v} \mathrm{Plu}-$ ronic F-127 (Invitrogen), in external solution. Images were acquired using MetaMorph software v7 and displayed as the ratio of $340-380 \mathrm{~nm}$. Neurons were identified by eliciting calcium responses with a high potassium solution $(140 \mathrm{~mm})$ at the end of each experiment. Neurons were considered sensitive to an agonist if the average ratio during the $30 \mathrm{~s}$ following agonist application was $\geq 15 \%$ above baseline. Image analysis was performed using custom MATLAB scripts.

Multiplex in situ hybridization. DRG sections cut at $25 \mu \mathrm{m}$ thickness were processed for RNA in situ detection using an RNAscope Fluorescent Detection Kit according to the manufacturer's instructions (Advanced Cell Diagnostics) with the following modifications: upon harvesting, DRG were fixed in $4 \%$ paraformaldehyde for $15 \mathrm{~min}$ and then incubated in $30 \%$ sucrose for $2 \mathrm{~h}$ at $4^{\circ} \mathrm{C}$. DRG were embedded in optimal cutting temperature compound (Sakura) and stored at $-80^{\circ} \mathrm{C}$ until sectioned. The following RNAscope probes were used: $\operatorname{Trpm} 8$ (420451-C3, mouse), Scn1a (434181-C2, mouse), Scn8a (434191-C2, mouse), Scn9a (313341C2, mouse), and Scn10a (426011-C2, mouse). In situ hybridization was followed by incubation at $4^{\circ} \mathrm{C}$ overnight with a rabbit anti-dsRed (1: 3000; Clontech, 632475) primary antibody. Sections were then incubated at room temperature for $1 \mathrm{~h}$ with a goat anti-rabbit AlexaFluor 594conjugated secondary antibody (ThermoFisher Scientific, A-11012). Samples were mounted with Fluoromount-G (Fisher Scientific). Specimens were imaged in three dimensions ( $1 \mu \mathrm{m}$ axial steps) on a Zeiss Exciter confocal microscope (LSM 5) equipped with a $40 \times 1.3 \mathrm{NA}$ objective lens. Images were analyzed using ImageJ software. Neurons considered positive for a given $\mathrm{Na}_{\mathrm{V}}$ subunit had signal $\geq 1$ SD above background.

Experimental design and statistical analysis. Summary data are presented as mean $\pm \mathrm{SD}$ from $n$ cells. For quantitative analysis of in situ hybridization data, at least three biological replicates per condition were used and the investigator was blinded to $\mathrm{Na}_{\mathrm{V}}$ subunit for analysis. Statistical differences between menthol-sensitive and menthol-insensitive populations were assessed using an unpaired Student's $t$ test (two-tailed) for normally distributed datasets. A Mann-Whitney test was used for populations that did not conform to Gaussian distributions or had different variances. To estimate $\mathrm{IC}_{50}$ values for $\mathrm{Na}_{\mathrm{V}}$ antagonists, inhibitor versus response curves were fit with the following relation: Normalized current $=100 /\left[1+(\right.$ Inhibitor $\left.) / \mathrm{IC}_{50}\right]$. Kinetic data were fit with single or double-exponential relations. The voltage dependence of slow inactivation was fit with the Boltzmann equation: Fraction available $=$ Minimum $+\left([\right.$ Maximum $\left.-\operatorname{Minimum}] /\left[1+\exp \left(V_{50} V_{\mathrm{m}}\right) / k\right]\right)$, where $V_{50}$ denotes the membrane potential at which half the channels are inactivated and $k$ denotes the Boltzmann constant/slope factor. Differences between fits were assessed with an Extra sum-of-squares $F$ test. Statistical tests and fit parameters are listed in Results and/or figure legends. Statistical significance in each case is denoted as follows: ${ }^{\star} p<0.05,{ }^{* *} p<0.01$, ${ }^{\star * *} p<$ 0.001 , and ${ }^{* * * *} p<0.0001$. Statistical tests and curve fits were performed using Prism 7.0 (GraphPad Software).

\section{Results}

Menthol-sensitivity is restricted to Vglut $3{ }^{\text {lineage }}$ DRG neurons Vglut ${ }^{\text {lineage }}$ sensory neurons are a heterogeneous population. To identify functionally distinct subpopulations within this group, we tested the responsiveness of Vglut $3{ }^{\text {lineage }}$ neurons to capsaicin, chloroquine and menthol (Fig. 1), which activate nociceptors, pruritoceptors, and cold receptors, respectively. We performed calcium microfluorimetry while applying various chemosensory stimuli to acutely cultured DRG neurons $(<24 \mathrm{~h})$ harvested from adult male and female Slc17a $8^{i C r e} ;$ Rosa $26^{\text {Ailu }}$ mice. In these mice, neurons that express Vglut3 at any point during development are labeled with a TdTomato fluorescent reporter (Fig. 1A). Neurons were identified by robust calcium responses to high-potassium depolarization (784 total DRG neurons, 331 Vglut3 lineage, 453 non-Vglut $3^{\text {lineage }}, n=3$ mice; Fig. $\left.1 B-D\right)$. Approximately $8 \%$ of Vglut ${ }^{\text {lineage }}$ neurons were activated by the TRPM 8 agonist menthol, whereas no non-Vglut 3 lineage neurons responded to the compound (Fig. 1E). Conversely, both populations contained neurons that were activated by the TRP vanilloid 1 (TRPV1) agonist capsaicin; however, comparatively fewer Vglut 3 lineage neurons were capsaicin-sensitive compared with non-Vglut 3 lineage neurons ( $\sim 9 \%$ vs $\sim 46 \%$, respectively). Few neurons of either group responded to both menthol and capsaicin (5/331 Vglut3 ${ }^{\text {lineage }}$ neurons), or to chloroquine (1/331 Vglut ${ }^{\text {lineage }}$ neurons and $4 / 453$ non-Vglut $3{ }^{\text {lineage }}$ neurons), a pruritogen that signals through MrgprA3 and TRP ankyrin 1 (TRPA1; Wilson et al., 2011). Interestingly, a comparison of un-normalized baseline fura-2 ratios showed that menthol-sensitive neurons had slightly elevated baseline calcium signals compared with mentholinsensitive neurons $\left(F_{340} / F_{380}=0.52 \pm 0.05\right.$ vs $0.45 \pm 0.03, n=$ 5 coverslips, $p=0.029$, unpaired Student's $t$ test, two-tailed; Fig. $1 F$ ). This analysis builds upon prior work (Draxler et al., 2014) by demonstrating that menthol sensitivity is restricted to the Vglut $3^{\text {lineage }}$ population.

The majority of menthol-sensitive DRG neurons have small somata and give rise to unmyelinated axons (Takashima et al., 2007; Dhaka et al., 2008). Thus, we targeted small-diameter, Vglut ${ }^{\text {lineage }}$ neurons with a membrane capacitance $\left(C_{\mathrm{m}}\right) \leq 25 \mathrm{pF}$ for functional analysis. Neurons that did not meet these criteria were not analyzed further by electrophysiology. Using gap-free current-clamp recordings, we asked whether these neurons fire action potentials in response to menthol application $(100 \mu \mathrm{M})$. Half of small-diameter Vglut $3^{\text {lineage }}$ neurons (31/62 neurons) fired trains of action potentials in response to menthol application (Fig. 2A). A subset of neurons were subsequently exposed to $1 \mathrm{mM}$ menthol, which activates TRPM8 ion channels but inhibits TRPA1 (Karashima et al., 2007; Xiao et al., 2008). All neurons examined showed a dose-dependent increase in menthol-evoked firing rates (Fig. 2B), suggesting that menthol elicits firing through TRPM8 rather than TRPA1 in Vglut ${ }^{\text {lineage }}$ DRG neurons. We noted that menthol-sensitive neurons were among the smallest DRG neurons in vitro, whereas menthol-insensitive neurons were more varied in size (Fig. $2 C$ ). Consistent with this observation, the distribution of $C_{\mathrm{m}}$ among these mentholsensitive neurons was well fit by a single Gaussian distribution $\left(R^{2}=0.986 ; 8.1 \pm 2.9\right.$ pF; Fig. $\left.2 D\right)$. Conversely, mentholinsensitive neurons were better fit by a double Gaussian distribution $\left(R^{2}=0.818\right)$, with the two populations having means of $8.7 \pm 3.4$ and $20.6 \pm 2.0 \mathrm{pF}$ (Fig. $2 D$ ). These data suggest that menthol-sensitive Vglut $3{ }^{\text {lineage }}$ neurons are a more homogenous subpopulation compared with menthol-insensitive Vglut3 lineage neurons.

\section{Menthol-sensitive Vglut $3^{\text {lineage }}$ neurons fire robustly at room temperature}

We next asked whether intrinsic excitability properties differed between menthol-sensitive and insensitive Vglut ${ }^{\text {lineage }}$ neurons. During gap-free recordings, we noted that $87 \%$ (27/31) of menthol-sensitive Vglut $3{ }^{\text {lineage }}$ neurons exhibited unusually robust action potential firing before menthol application. Two firing patterns were observed, sustained and phasic firing (Fig. $2 E, F)$. Of the menthol-sensitive neurons that exhibited nonevoked activity, 44\% exhibited phasic firing, whereas 56\% maintained sustained firing during gap-free recordings. 
A

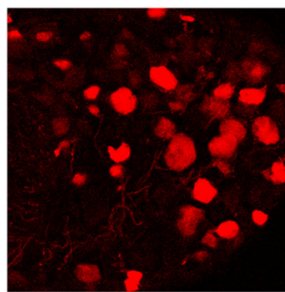

TdTomato

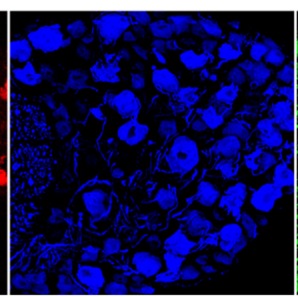

$\mathrm{NFH}$

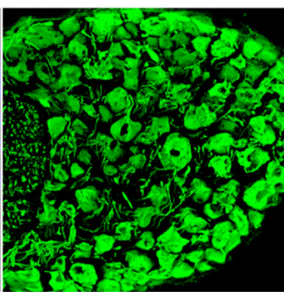

ß3-Tubulin

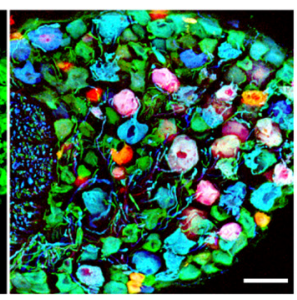

Merge
B

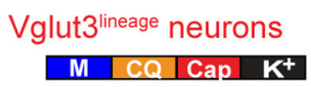

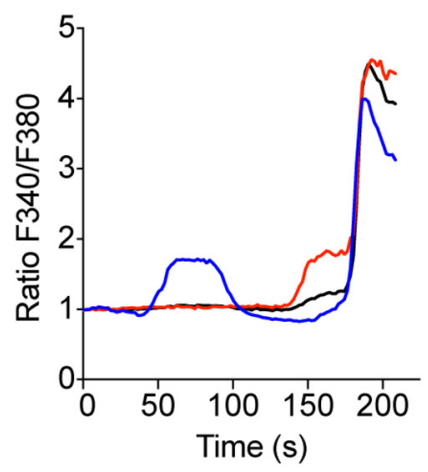

C

Non-Vglut $3^{\text {lineage }}$ neurons

D
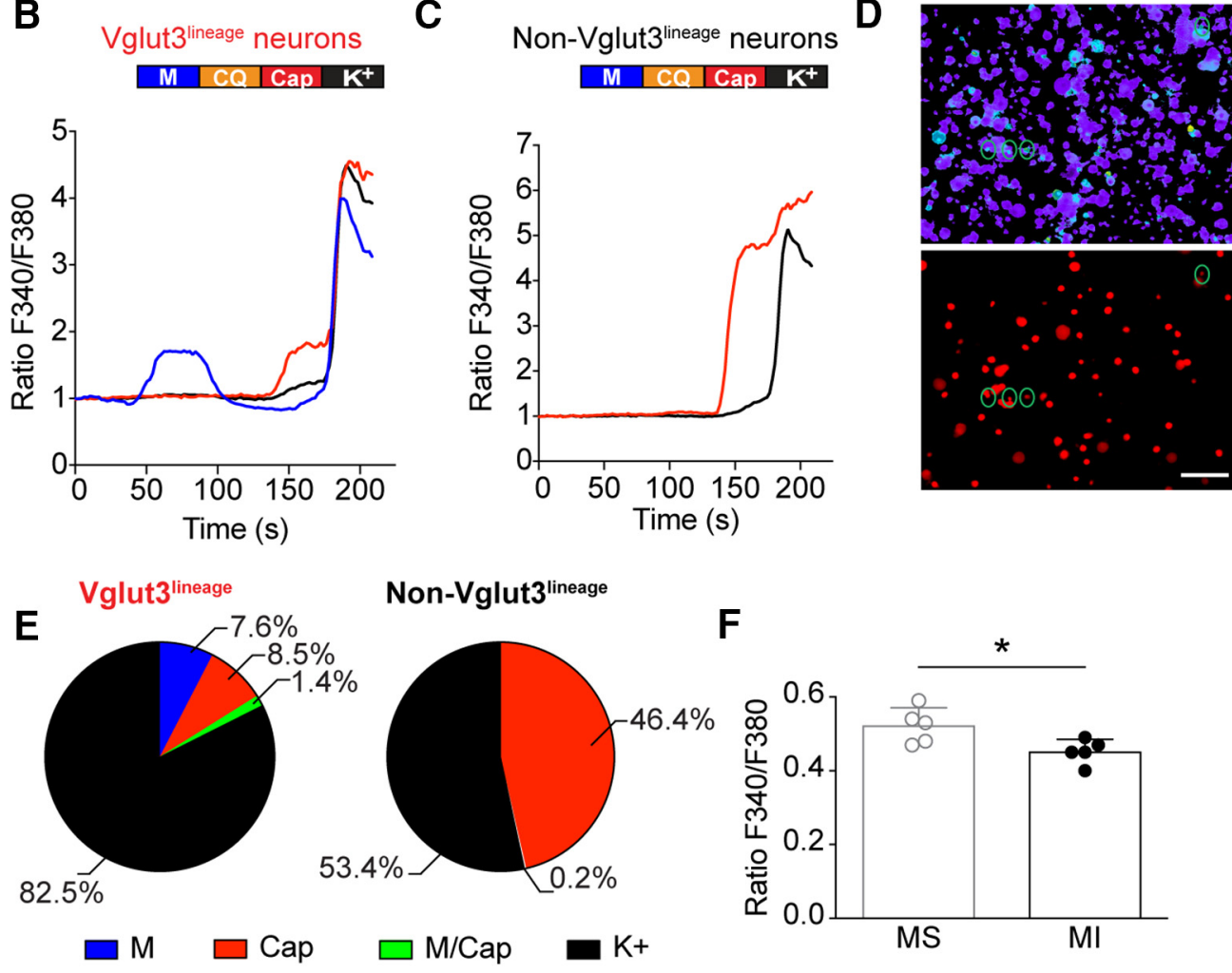

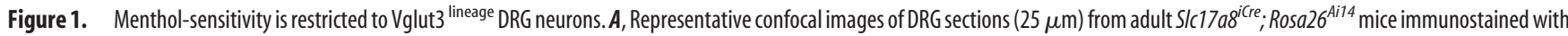
anti-DsRed (TdTomato; red), anti-neurofilament heavy ( $N F H$; blue), and anti- $\beta 3$-Tubulin (green). Images were acquired using a $20 \times 0.8$ NA air objective. $\boldsymbol{B}, \boldsymbol{C}$, Baseline normalized, representative traces depicting Fura2-AM ratio (F340/F380) versus time traces of averaged responses from Vglut3 ${ }^{\text {lineage }}(\boldsymbol{B})$ and non-Vglut3 ${ }^{\text {lineage }}$ (C) DRG neurons to various chemosensory stimuli [menthol (M) $100 \mu \mathrm{m}$, blue trace; chloroquine (CQ) $1 \mathrm{~mm}$; capsaicin (Cap) $1 \mu \mathrm{m}$, red trace; and high $\mathrm{K}^{+}$Ringer's $\left(\mathrm{K}^{+}\right) 140 \mathrm{mM}$, black trace]. Colored bar indicates time of agonist application. $\boldsymbol{D}$, Images of calcium transients in live, dissociated SIC17a8 ${ }^{\text {icre; }}$; Rosa2 $6^{A i 14}$ DRG neurons quantified in $\boldsymbol{B}$ and $\boldsymbol{C}$. Top, Fura2-AM calcium microfluorimetry following menthol application. Green circles indicate mentholsensitive DRG neurons. Bottom, Fluorescent image showing TdTomato-expressing (Vglut3 $\left.{ }^{\text {lineage }}\right)$ DRG neurons. E, Quantification of percentage of Vglut3 ${ }^{\text {lineage }}(n=331)$ and non-Vglut3 ${ }^{\text {lineage }}(n=$ 453) neurons responding to individual agonists. $\boldsymbol{F}$, Quantification of baseline calcium signals between Vglut $3{ }^{\text {lineage }}$ menthol-sensitive neurons and menthol-insensitive neurons (both Vglut $3{ }^{\text {lineage }}$ and non-Vglut $\left.3{ }^{\text {lineage }}\right)$. Significance was determined using an unpaired Student's $t$ test. ${ }^{*} p<0.05$. Data represented as mean \pm SD. Scale bars, $100 \mu \mathrm{m}$.

Menthol-sensitive neurons with sustained action potential discharges showed higher average firing frequencies compared with burst firing frequencies of phasic neurons (Fig. $2 F$ ). By contrast, few menthol-insensitive neurons exhibited non-evoked firing during gap-free recordings (4/31), and these produced only occasional action potentials. This ongoing activity in mentholsensitive neurons is consistent with the elevated baseline flura-2 fluorescence observed during calcium microfluorimetry experiments (Fig. $1 F$ ), as well as ex vivo data showing sustained firing upon cold or menthol-stimulation of TRPM8-expressing DRG neuron receptive fields (Jankowski et al., 2017). Together, these results suggest that the menthol-sensitive Vglut $3{ }^{\text {lineage }}$ population has heightened excitability under our in vitro recording conditions and that, within the this population, firing properties vary.

The ability of menthol-sensitive neurons to fire robustly at room temperature, an activating stimulus for TRPM8 (McKemy et al., 2002; Andersson et al., 2004; Tajino et al., 2011; Fujita et al., 2013; Morenilla-Palao et al., 2014; Jankowski et al., 2017; Pertusa et al., 2018), led us to ask whether this firing was dependent upon TRPM8 ion channels. We applied the selective inhibitor, PBMC (25 nM; Knowlton et al., 2011) to menthol-sensitive neurons and analyzed its effect on action potential firing at room temperature. Whereas vehicle application did not have a significant effect on firing rates, PBMC drastically reduced action potential firing at room temperature within $2 \mathrm{~min}$ of drug application $(n=3$ neurons per group, $p=0.0035$, unpaired Student's $t$ test; Fig. $2 G, H$ ). Thus, activation of TRPM8 ion channels mediates robust ongoing action potential firing in menthol-sensitive Vglut $3^{\text {lineage }}$ neurons.

Collectively, these data demonstrate that menthol-sensitive neurons are a highly excitable subpopulation of small-diameter Vglut $3^{\text {lineage }}$ DRG neurons, capable of maintaining sustained action potential firing in vitro at room temperature. 
A

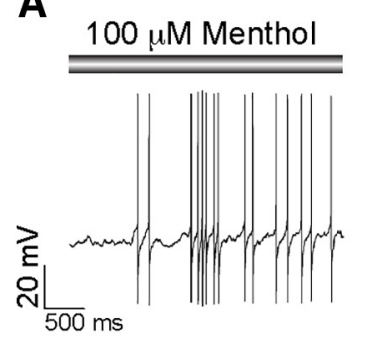

C

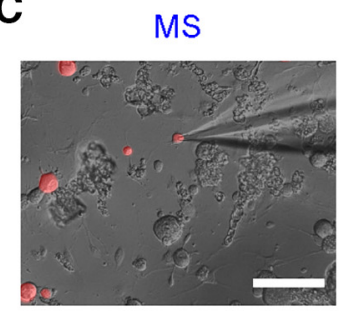

E

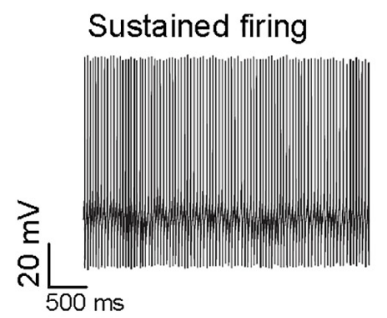

G

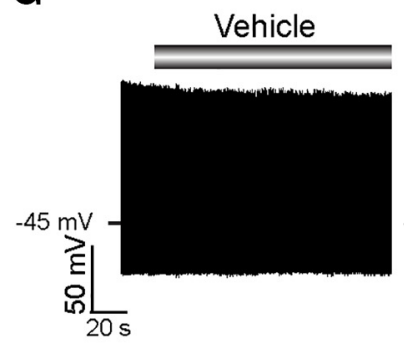

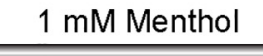

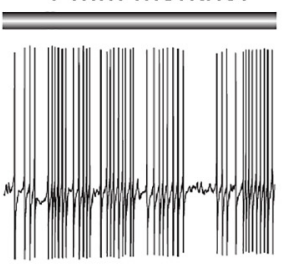

MI
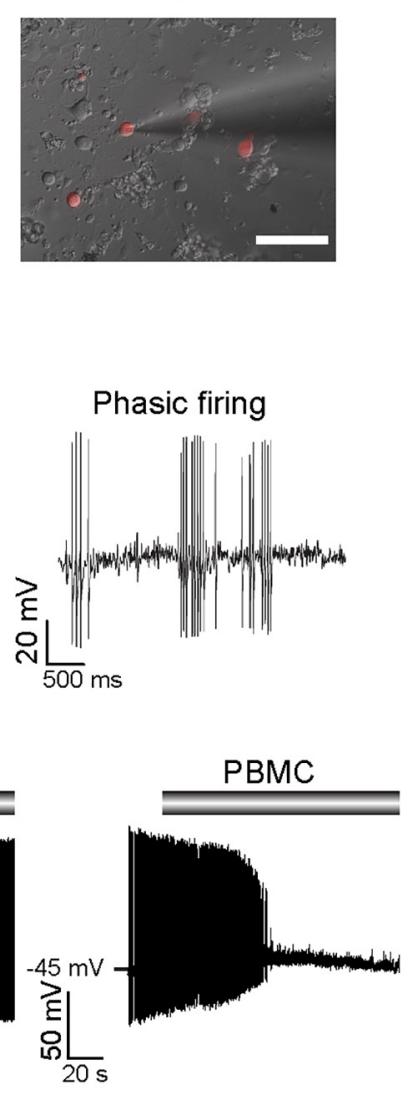

B

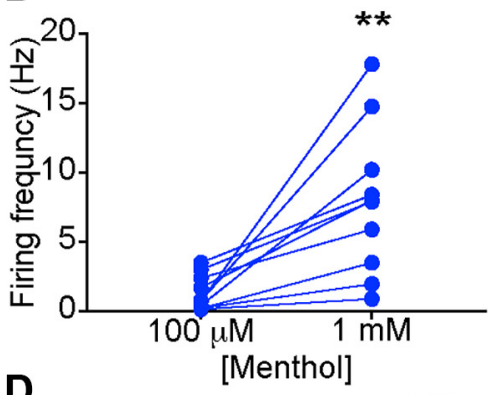

D

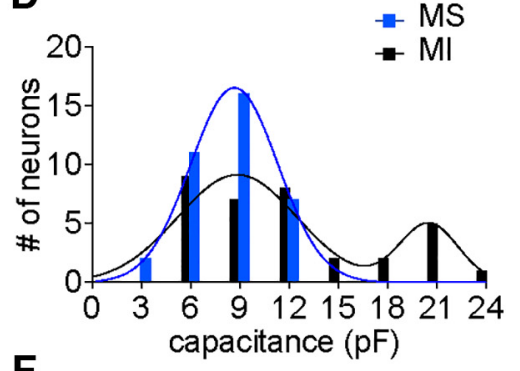

$F$

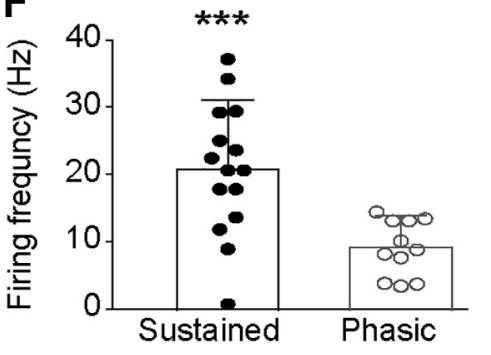

H

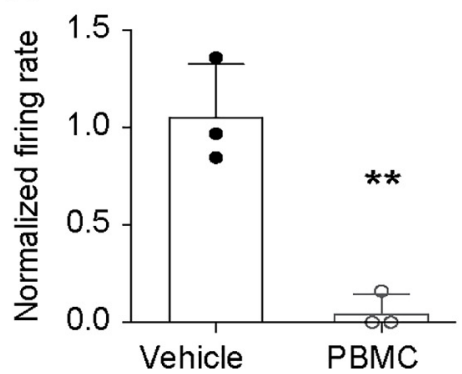

Figure 2. Menthol-sensitive Vglut $3^{\text {lineage }}$ neurons fire action potential discharges at room temperature. $A$, Representative current-clamp recording from a menthol-sensitive Vglut 3 lineage $D R G$ neuron. Gray bar indicates menthol application (100 $\mu \mathrm{m}$, left; $1 \mathrm{~mm}$, right). B, Quantification of firing rates in response to $100 \mu \mathrm{m}$ and $1 \mathrm{~mm}$ menthol. Lines connecting symbols indicate paired observations. Significance was determined using a paired Student's $t$ test (two-tailed). ${ }^{* *} p=0.0036$. C, Representative differential interference contrast image (20×, $0.75 \mathrm{NA}$ air objective) of a menthol-sensitive (MS; left) and a menthol-insensitive (MI; right) DRG neuron in culture during electrophysiological recordings. TdTomato fluorescence indicates Vglut3 ${ }^{\text {cre }}$ expression at some point

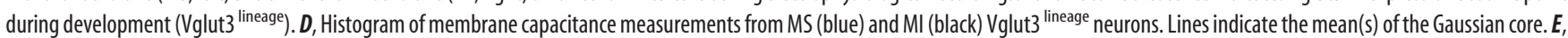
Left, Representative current-clamp recording from a MS neuron exhibiting sustained firing at room temperature. Right, A different MS neuron firing with a phasic action potential discharge pattern. $\boldsymbol{F}$, Quantification of average non-evoked firing frequency of MS V glut3 $3^{\text {lineage }}$ neurons at room temperature. Each individual point represents the average firing frequency of a single neuron over a $5 \mathrm{~s}$ period. Firing frequencies for phasic-firing neurons were quantified during bursts of action potentials only. Significance was determined using an unpaired Student's $t$ test (two-tailed). ${ }^{* * *} p=$ 0.0009. G, Left, Representative current-clamp trace of room temperature action potential firing in a MS neuron. Vehicle treatment did not impact firing rate. Gray bar indicates vehicle application. Right, Representative current-clamp trace of inhibition of action potential firing in a MS neuron following application of the TRPM8 blocker, PBMC ( $25 \mathrm{nm).} \mathrm{Gray} \mathrm{bar} \mathrm{indicates} \mathrm{PBMC} \mathrm{application.} \boldsymbol{H}$, Quantification of relative firing rate following 90 s of vehicle or PBMC treatment. Significance was determined using an unpaired Student's $t$ test. ${ }^{* *} p<0.01$. Data represented as mean \pm SD. Scale bars, $100 \mu \mathrm{m}$.

Intrinsic excitability differs between Vglut3-lineage mentholsensitive and menthol-insensitive neurons

To investigate the heightened intrinsic excitability in mentholsensitive DRG neurons, we compared responses of mentholsensitive and -insensitive Vglut $3^{\text {lineage }}$ neurons to 500 ms current injections using phase plot analysis (Fig. $3 A, B$ ). The threshold for action potential firing in menthol-sensitive neurons was signifi- cantly hyperpolarized $(-28.5 \pm 6.6 \mathrm{mV}, n=28)$ compared with menthol-insensitive neurons $(-22.2 \pm 10.4 \mathrm{mV}, n=31, p=$ 0.0269, unpaired Student's $t$ test; Fig. 3C). Menthol-sensitive neurons also fired more action potentials in response to a current injection of $50 \mathrm{pA}$ (Fig. 3D). Action potential duration at the base (see Materials and Methods) was significantly shorter in menthol-sensitive neurons compared with menthol-insensitive 

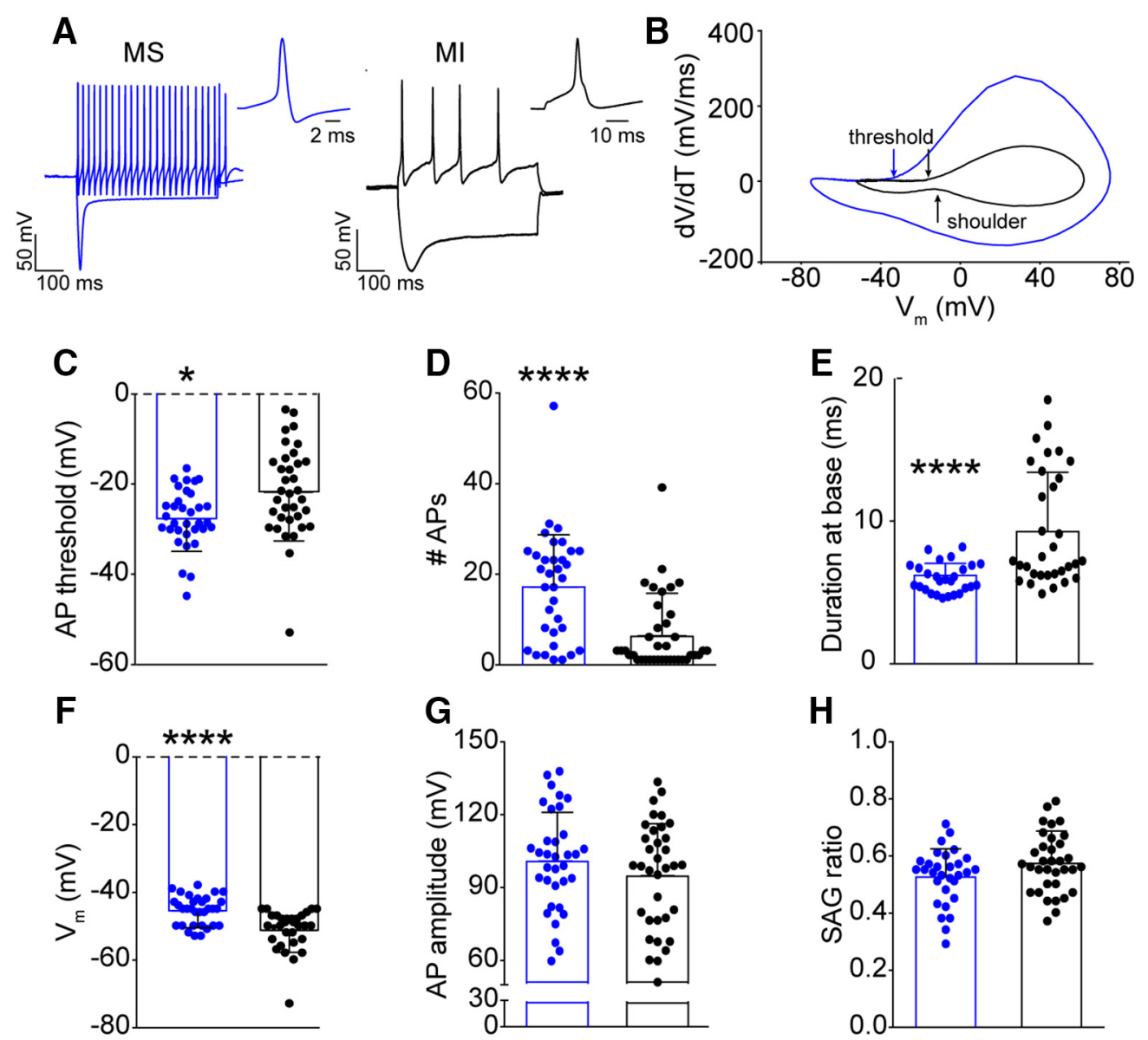

Figure 3. Intrinsic excitability of menthol-sensitive Vglut 3 lineage DRG neurons. A, Representative current-clamp traces from a menthol-sensitive (MS; left, blue) and -insensitive (MI; right, black) Vglut $3{ }^{\text {lineage }}$ DRG neuron in response to -200 and $50 \mathrm{pA}$ current injections. The single action potential for each represents the first action potential elicited by the $50 \mathrm{pA}$ current injection. $\boldsymbol{B}$, Phase-plots of single action potentials shown in $\boldsymbol{A}$. Plots show the first derivative of the somatic membrane potential (dV/dT) versus the instantaneous somatic membrane potential. The blue curve represents the MS neuron and the black curve represents the MI neuron. Arrows indicating "threshold" are the points at which the membrane potential of the phase plot slope reached $10 \mathrm{mV} \mathrm{ms}^{-1}$. The arrow indicating shoulder represents the momentary slowing of membrane repolarization seen in a subpopulation of menthol-insensitive neurons. $\mathbf{C}-\boldsymbol{H}$, Quantification of action potential threshold $(\boldsymbol{C})$, number of action potentials generated in response to a $50 \mathrm{pA}$ current injection (D), duration at base $(\boldsymbol{E})$, membrane potential $(\boldsymbol{F})$, membrane potential $(\boldsymbol{G})$, and sag ratio $(\boldsymbol{H})$ for MS (blue) and MI (black) Vglut3 lineage DRG neurons. Significance was determined using unpaired Student's $t$ tests for normally distributed populations $(\boldsymbol{C}, \boldsymbol{E}, \boldsymbol{G}, \boldsymbol{H})$ or Mann-Whitney tests for non-normal distributions $(\boldsymbol{D}, \boldsymbol{F}) .{ }^{*} p<0.05,{ }^{* * * *} p<0.0001$. Bars denote mean $\pm S D$ and filled circles show data from each neuron.

neurons (Fig. 3E). Interestingly, in gap-free recordings before menthol application, menthol-sensitive neurons had significantly more depolarized membrane potentials $\left(V_{\mathrm{m}}\right)$ than menthol-insensitive neurons $(-45.5 \pm 4.4 \mathrm{mV}$ vs $-51.2 \pm 5.8$ $\mathrm{mV}, n=31$ for each group, $p<0.0001$, Mann-Whitney test; Fig. $3 F)$. Thus, menthol-sensitive Vglut $3^{\text {lineage }}$ neurons maintain a $V_{\mathrm{m}}$ that more closely borders action potential threshold compared with menthol-insensitive Vglut ${ }^{\text {lineage }}$ neurons. Conversely, action potential amplitude, and membrane voltage sag did not differ between the two populations (Fig. 3G,H). Together, these data provide evidence that menthol-sensitive Vglut $3^{\text {lineage }}$ neurons have more excitable membrane properties than menthol-insensitive Vglut $3{ }^{\text {lineage }}$ neurons.

Interestingly, consistent with their longer duration action potentials, $44 \%$ of menthol-insensitive neurons had a pronounced shoulder during the repolarization phase of the action potential (Fig. 3A,B). This shoulder was completely absent in mentholsensitive neurons. The presence of a shoulder is attributed to sodium currents mediated by TTX-resistant $\mathrm{Na}_{\mathrm{V}} 1.8$ and $\mathrm{Na}_{\mathrm{V}} 1.9$ channels (Blair and Bean, 2002). Thus, a differential contribution of $\mathrm{Na}_{\mathrm{V}}$ subunits to action potential firing in these two popula- tions of Vglut $3^{\text {lineage }}$ neurons could underlie the observed differences in excitability.

Differences in $\mathrm{Na}_{\mathrm{V}}$ current slow inactivation kinetics in smalldiameter Vglut $3^{\text {lineage }}$ neurons

$\mathrm{Na}_{\mathrm{V}}$ slow inactivation has been linked to adaptation of action potential firing in small-diameter DRG neurons, whereby sequestration of tetrodotoxin-resistant $\mathrm{Na}_{\mathrm{V}} \mathrm{s}$ subunits $\mathrm{Na}_{\mathrm{V}} 1.8$ and $\mathrm{Na}_{\mathrm{V}} 1.9$ in the slow inactivated state restricts the duration of action potential discharges in response to sustained stimulation (Blair and Bean, 2003). As we found that menthol-sensitive Vglut $3^{\text {lineage }}$ neurons are capable of maintaining prolonged action potential discharges for several minutes in vitro (Fig. 2) and fire robustly in response to current injection (Fig. 3), we hypothesized that $\mathrm{Na}_{\mathrm{V}}$ slow inactivated states are unstable in menthol-sensitive Vglut $3^{\text {lineage }}$ neurons. To test this model, we first measured $\mathrm{Na}_{\mathrm{V}}$ entry into slow inactivation by delivering a conditioning pulse from -100 to $0 \mathrm{mV}$ for $50-1600 \mathrm{~ms}$ between $3 \mathrm{~ms}$ test steps to $-20 \mathrm{mV}$ (Fig. $4 A$ ). Consistent with our hypothesis, entry of $\mathrm{Na}_{\mathrm{V}}$ currents into the slow inactivated state was almost fourfold slower in menthol-sensitive neurons compared with menthol-insensitive neurons ( $\tau=1485 \mathrm{~ms}$, 
A

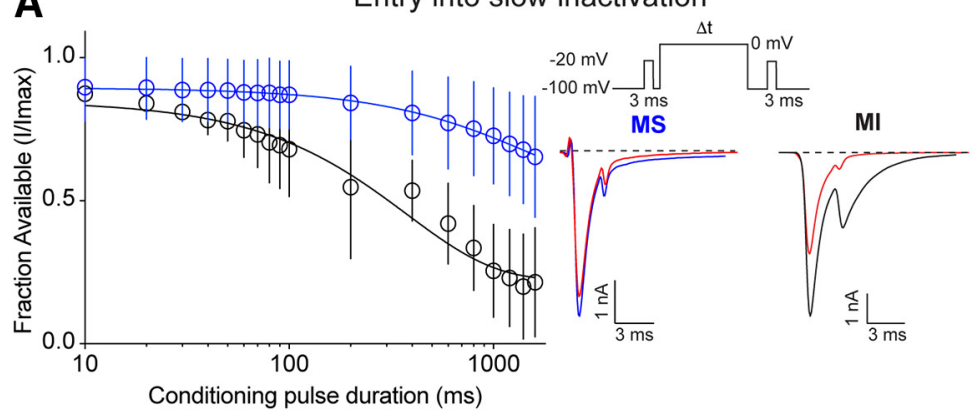

B
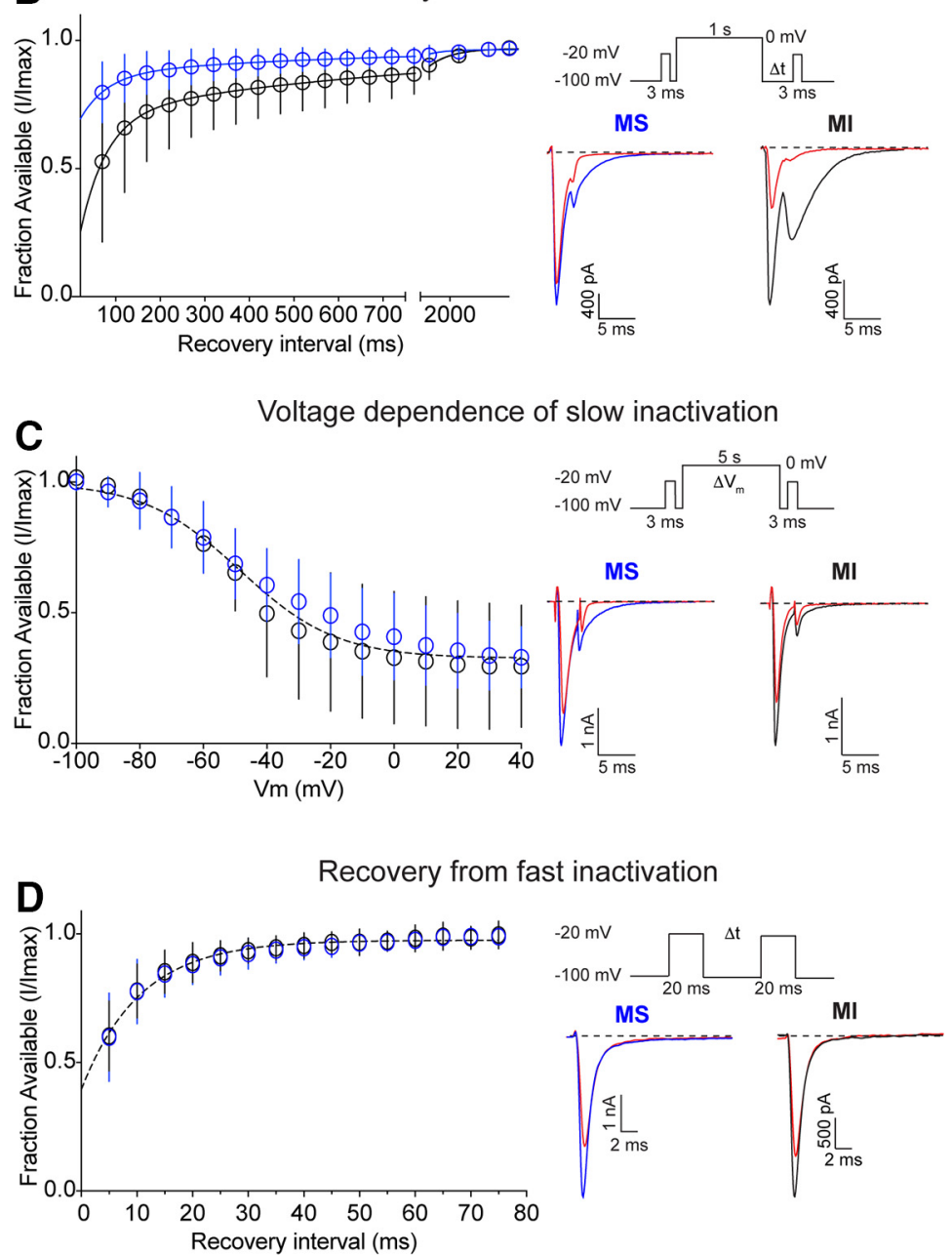

Figure 4. $\quad \mathrm{Na}_{\mathrm{V}}$ recovery from slow inactivation in small-diameter Vglut3 3 lineage $D R G$ neurons. A, Left, Quantification of entry into slow inactivation for menthol-sensitive (MS; blue) and -insensitive (MI; black) Vglut $3^{\text {lineage }}$ DRG neurons. The current elicited following a conditioning pulse to $0 \mathrm{mV}$ is normalized to the current elicited during an initial test step and plotted against the duration of the conditioning pulse. Lines show exponential fits to the data. Top right, Voltage protocol used to measure $\mathrm{Na}_{\mathrm{v}}$ entry into slow inactivation. Channel slow inactivation was elicited by a conditioning pulse ranging from 10 to $1600 \mathrm{~ms}$. A test step to $-20 \mathrm{mV}$ given $12 \mathrm{~ms}$ after the conditioning pulse was used to determine entry into slow inactivation. Bottom right, Representative whole-cell voltage-clamp traces of currents elicited from MS and MI neurons. Blue or black traces represent initial test steps; red traces represent test pulses given after a $200 \mathrm{~ms}$ conditioning step. $\boldsymbol{B}$, Left, Quantification of recovery from slow inactivation kinetics for MS and MI neurons. Recovery during the second test step is normalized to the current during the initial test step and plotted against the recovery interval. Lines show double-exponential fits to the data. MS neurons: $n=9, \tau_{1}=571.1 \mathrm{~ms}, \tau_{2}=$ $59.5 \mathrm{~ms}$; Ml neurons: $n=6, \tau_{1}=764.6 \mathrm{~ms}, \tau_{2}=58.2 \mathrm{~ms} ; p<0.0001$, extra sum-of-squares $F$ test. Top right, Voltage protocol used to measure $\mathrm{Na}_{\mathrm{v}}$ recovery from slow inactivation. Slow inactivation was induced by a $1 \mathrm{~s}$ conditioning pulse to $0 \mathrm{mV}$. Recovery was assayed by $3 \mathrm{~ms}$ steps to $-20 \mathrm{mV}$ with increasing recovery durations, beginning at $50 \mathrm{~ms}$ following the conditioning pulse. Bottom right, Representative whole-cell voltage-clamp traces of currents elicited from a MS (blue) and a MI (black) neuron. Blue or black traces represent initial test steps; red traces represent pulses given $50 \mathrm{~ms}$ after the conditioning step. C, Left, Quantification of steady-state voltage dependence of slow inactivation. Both groups were well fit by a single Boltzmann equation $\left(V_{50}=-48.6\right.$ $\mathrm{mV}$, slope factor $=-15.6 \mathrm{mV}, n=7-8$ neurons per group, $p=0.1031$, extra sum-of-squares $F$ test). Top right, Protocol for $n=6$ vs $\tau=376.5 \mathrm{~ms}, n=5 ; p<0.0001$, extra sum-of-squares $F$ test). Notably, after a 1600 ms conditioning pulse, $\sim 65 \%$ of the initial $\mathrm{Na}_{\mathrm{V}}$ current in menthol-sensitive neurons was still present, whereas only $\sim 21 \%$ of the current remained in mentholinsensitive neurons. Thus, $\mathrm{Na}_{\mathrm{V}}$ currents in menthol-sensitive neurons are resistant to slow inactivation.

We next analyzed recovery from slow inactivation by delivering a $3 \mathrm{~ms}$ test pulse to $-20 \mathrm{mV}$, followed by a $1 \mathrm{~s}$ conditioning step from -100 to $0 \mathrm{mV}$, and a second 3 $\mathrm{ms}$ test pulse given at recovery intervals of increasing duration. Recovery time constants from both populations were well fit with double-exponential functions. Consistent with the slow inactivated state being unstable in menthol-sensitive Vglut 3 lineage neurons, $\mathrm{Na}_{\mathrm{V}}$ currents in these cells recovered faster from slow inactivation than those in menthol-insensitive neurons (Fig. 4B); however, note that the $1 \mathrm{~s}$ conditioning pulse did not drive all channels into the slow inactivated state. Sodium currents in menthol-sensitive Vglut $3^{\text {lineage }}$ neurons recovered from slow inactivation with an average weighted time constant of $244.3 \mathrm{~ms}$, whereas menthol-insensitive Vglut $3^{\text {lineage }}$ neurons recovered slower, with an average weighted time constant of 311.2 ms $(p<0.0001$, extra sum-of-squares $F$ test). Indeed, after $50 \mathrm{~ms}, \sim 80 \%$ of the $\mathrm{Na}_{\mathrm{V}}$ current had recovered in menthol-sensitive neurons compared with $\sim 50 \%$ in menthol insensitive neurons. The steady-state voltage dependence of slow inactivation was comparable in menthol-sensitive and -insensitive Vglut $3^{\text {lineage }}$ neurons (Fig. 4C). These data suggest that in menthol-sensitive neurons, slow inactivated states are less stable across membrane voltages. Finally, recovery from fast inactivation was not distinguishable between menthol-sensitive and -insensitive Vglut $3{ }^{\text {lineage }}$ neurons (Fig. $4 D)$.

$$
\longleftarrow
$$

measuring voltage dependence of slow inactivation. A conditioning pulse of $5 \mathrm{~s}$ to membrane potentials between -100 and $+40 \mathrm{mV}$ were followed by a $20 \mathrm{~ms}$ step to $-100 \mathrm{mV}$ and then a test step to $-20 \mathrm{mV}$. Bottom right, Representative traces of currents elicited from a MS (blue) and a MI (black) neuron. Red traces represent test pulses to $-40 \mathrm{mV}$. D, Left, Quantification of recovery from fast inactivation kinetics. Lines show monoexponential fits to the data. Top right, Protocol to measure recovery from fast inactivation. $A 20 \mathrm{~ms}$ step to -20 $\mathrm{mV}$ from $-100 \mathrm{mV}$ is followed by varying durations at the recovery potential $(-100 \mathrm{mV})$ before a second test step to $-20 \mathrm{mV}$. MS and MI datasets were well fit by a single monoexponential equation. $\tau=10.5 \mathrm{~ms}, n=10$ for both groups. Bottom right, Representative traces of currents elicited from a MS (blue) and a MI (black) neuron. Red traces represent test pulses $5 \mathrm{~ms}$ following the initial test step. Error bars indicate SD; absent error bars are smaller than symbols. 


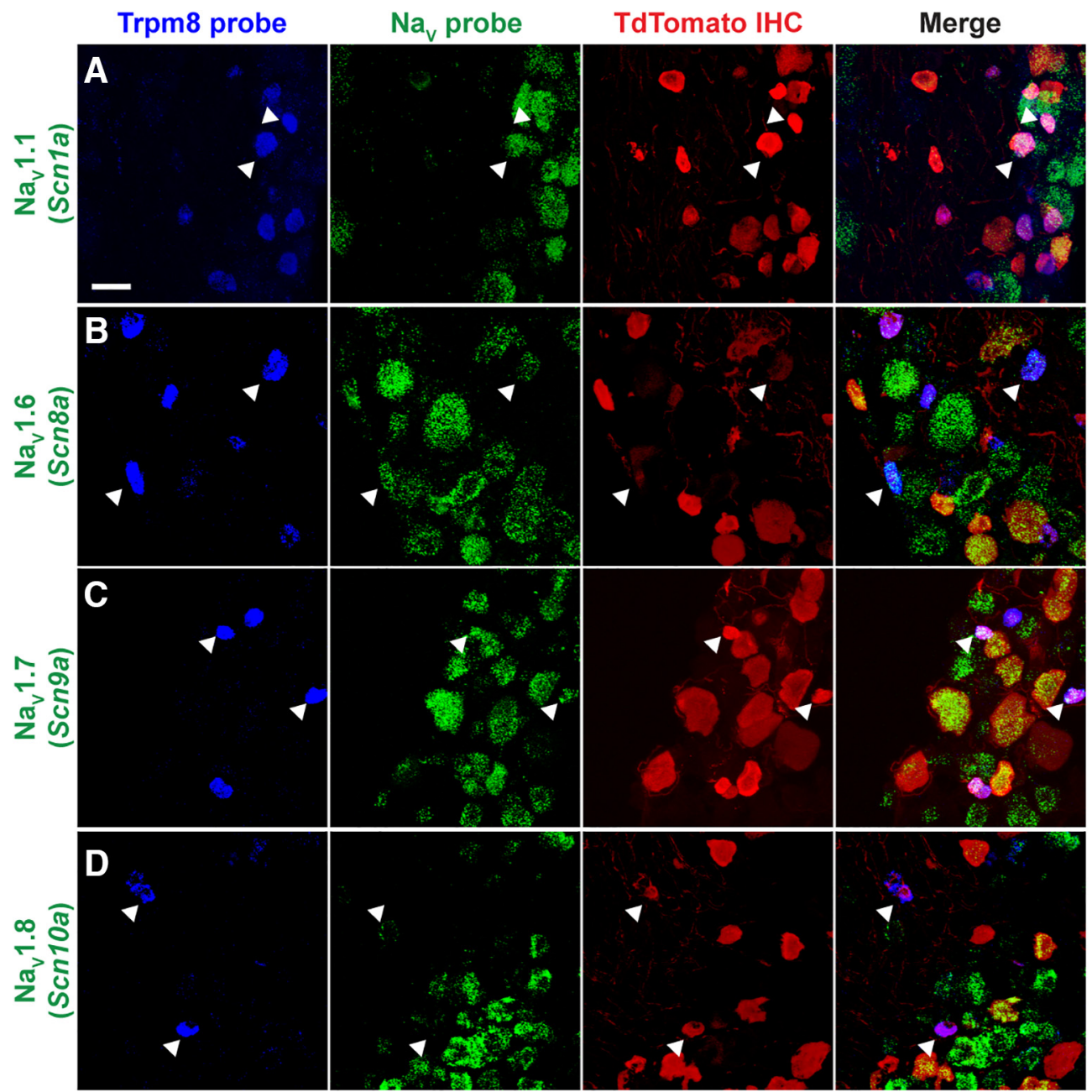

TRPM8+

$\mathbf{E}$

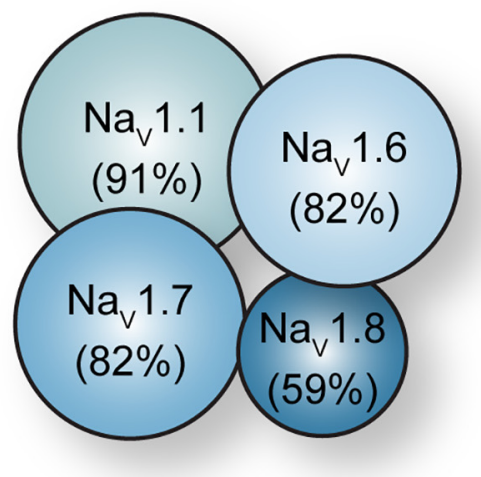

TRPM8-

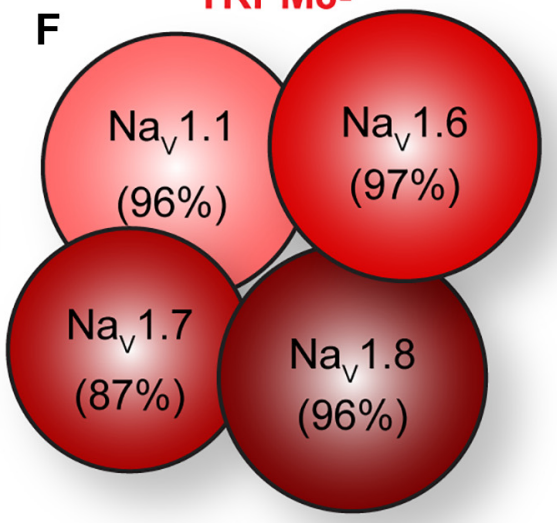

Figure 5. $\quad \mathrm{Na}_{\mathrm{v}}$ expression profile of small-diameter Vglut $3^{\text {lineage }} \mathrm{DRG}$ neurons. $\boldsymbol{A}-\boldsymbol{D}$, Representative confocal images of single molecule multiplex in situ hybridizations performed on cryosections of adult DRG (25 $\mu \mathrm{m})$. Images were acquired with a $40 \times, 1.3$ NA oil-immersion objective. Scale bar, $50 \mu \mathrm{m}$. Sections were hybridized with probes targeting TRPM8 (Trpm8; blue) and the following voltage-gated sodium channel subunits (green): (A) Na 1.1 (Scn1a), (B) Na 1.6 (Scn8a), (C) Na 1.7 (Scn9a), and (D) Na 1.8 (Scn10a). Sections were stained using immunohistochemistry with anti-dsRED (TdTomato; red) to label Vglut3 lineage neurons. White arrowheads indicate representative TRPM8 $+/ \mathrm{Na}_{V}+$ neurons. $E, F$, Schematic representation of the percentage of TRPM8 + $(\boldsymbol{E})$ or TRPM8 - $\boldsymbol{F}$ ) small-diameter Vglut $3{ }^{\text {lineage }}$ neurons that colabeled for each given $\mathrm{Na}_{\mathrm{V}}$ subunit.

Collectively, these data indicate that the slow inactivated state of $\mathrm{Na}_{\mathrm{V}} \mathrm{s}$ expressed in menthol-sensitive Vglut ${ }^{\text {lineage }}$ neurons is unstable, which could explain the capacity of these neurons to sustain action potential firing for prolonged periods of time. Moreover, the kinetics of slow inactivation we obtained for $\mathrm{Na}_{\mathrm{V}}$ currents in this population of small-diameter neurons suggest they do not rely upon TTX-resistant $\mathrm{Na}_{\mathrm{V}} \mathrm{s}$, which readily enter into the slow inactivated state (Blair and Bean, 2003; Choi et al., 2007). 
A
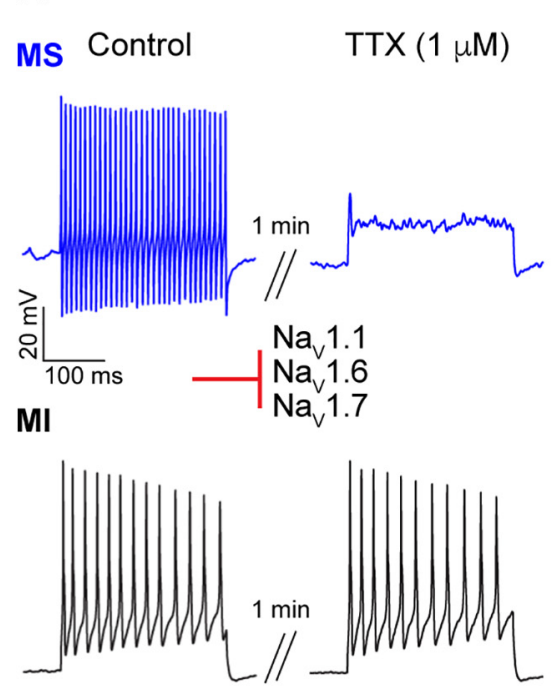

C

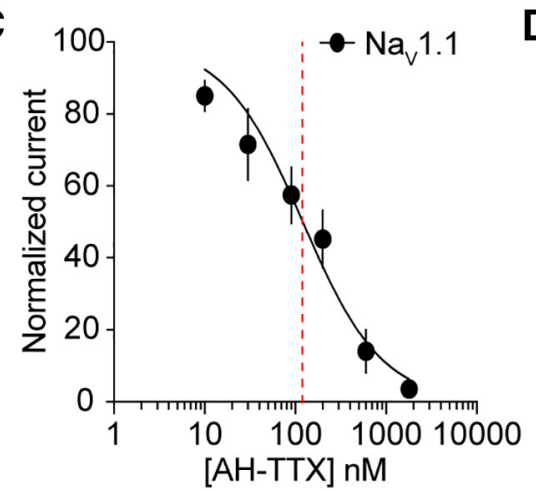

B

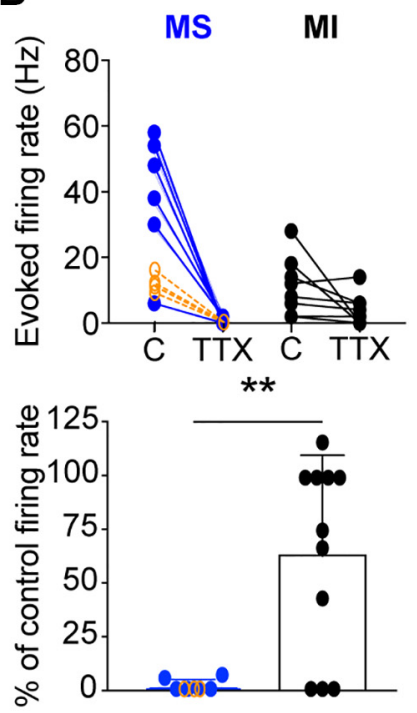

D

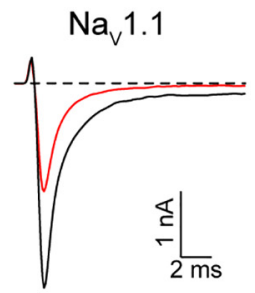

Figure 6. TTX-sensitive $\mathrm{Na}_{\mathrm{v}} \mathrm{s}$ mediate action potential firing in menthol-sensitive Vglut3 ${ }^{\text {lineage }}$ neurons. $\boldsymbol{A}$, Representative current-clamp traces from menthol-sensitive (MS; top, blue) and-insensitive (MI; bottom, black) Vglut3 ${ }^{\text {lineage }}$ DRG neurons before (left) and after (right) a 1 min application of TTX $(1 \mu \mathrm{M})$. B, Top, Quantification of firing rates before and after TTX application $(n=$ $6 \mathrm{MS}$ neurons, $n=11 \mathrm{MI}$ neurons). Lines connecting symbols indicate paired observations. Bottom, Quantification of the percentage of control firing rate that remained following TTX application for MS and MI neurons. Blue symbols indicate MS neurons and black symbols indicate MI neurons. Orange symbols indicate firing rates of MS neurons before and after application of $300 \mathrm{~nm}$ TTX $(n=4)$. C, A dose-response curve obtained for inhibition of recombinant human $\mathrm{Na}_{\mathrm{V}} 1.1$ channels stably expressed in HEK293 cells by AH-TTX, a blocker of $\mathrm{Na}_{\mathrm{y}} 1.6$ channels. Red dashed line indicates apparent $\mathrm{IC}_{50}$. D. Representative whole-cell voltage-clamp traces of $\mathrm{Na}_{\mathrm{v}} 1.1$ currents elicited from HEK293 cells. Black trace indicates current elicited before application of AH-TTX. Red trace shows reduction in $\mathrm{Na}_{v} 1.1$ current after application of $200 \mathrm{~nm}$ AH-TTX. Red inhibitory sign indicates the inhibition of denoted $\mathrm{Na}_{V}$ subunits by the blocker. ${ }^{* *} p<0.01$.

\section{$\mathrm{Na}_{\mathrm{V}}$ expression profiles in small-diameter Vglut ${ }^{\text {lineage }}$ DRG neurons}

Given the functional differences in membrane excitability and $\mathrm{Na}_{\mathrm{V}}$ currents between menthol-sensitive and -insensitive Vglut3 ${ }^{\text {lineage }}$ neurons, we next asked whether these two populations have distinct expression profiles of $\mathrm{Na}_{\mathrm{V}} \alpha$ subunits, nine of which are encoded in the mammalian genome $\left(\mathrm{Na}_{\mathrm{V}} 1.1-\mathrm{Na}_{\mathrm{V}} 1.9\right.$; Catterall, 2012). To do so, we performed single-molecule multiplex in situ hybridization experiments (Fig. 5). Menthol-sensitive Vglut ${ }^{\text {lineage }}$ neurons were identified based on TRPM8 mRNA expression. Similarly sized, small-diameter Vglut $3{ }^{\text {lineage }}$ neurons lacking TRPM8 expression were considered menthol-insensitive neurons.

We focused our analysis on $\mathrm{Na}_{\mathrm{V}} 1.1, \mathrm{Na}_{\mathrm{V}} 1.6, \mathrm{Na}_{\mathrm{V}} 1.7$, and $\mathrm{Na}_{\mathrm{V}} 1.8$ subunits, which are commonly found in adult murine DRG neurons (Black et al., 1996; Ho and O'Leary, 2011; Fig. $5 A-D)$. Quantification of $\mathrm{Na}_{\mathrm{V}}$ mRNA staining from 848 DRG neurons ( $n=3$ animals) revealed broad and comparable expres- sion of TTX-sensitive $\mathrm{Na}_{\mathrm{V}} 1.1, \mathrm{Na}_{\mathrm{V}} 1.6$, and $\mathrm{Na}_{\mathrm{V}} 1.7$ subunits between TRPM8 ${ }^{+}$ and TRPM8 ${ }^{-}$small-diameter Vglut ${ }^{\text {lineage }}$ neurons (Fig. 5E,F). Transcripts for the TTX-resistant isoform $\mathrm{Na}_{\mathrm{V}} 1.8$, although widely expressed, was lower in TRPM8 ${ }^{+}$ compared with TRPM8 ${ }^{-}$Vglut $3^{\text {lineage }}$ neurons, [59\% (47/80) vs 96\% (97/101), respectively]. These data suggest that differential expression of $\mathrm{Na}_{\mathrm{V}} \mathrm{s}$ at the mRNA level cannot account for the differences in excitability observed between mentholsensitive and -insensitive Vglut 3 lineage DRG neurons.

\section{TTX-sensitive $\mathrm{Na}_{\mathrm{V}} s$ mediate action potential firing in menthol-sensitive Vglut $3^{\text {lineage }}$ neurons}

Considering the overlap in $\mathrm{Na}_{\mathrm{V}}$ mRNA expression between putative mentholsensitive and -insensitive neurons, we next used a pharmacological approach to assess the complement of functional $\mathrm{Na}_{\mathrm{V}}$ isoforms in these two populations. We first asked whether evoked firing from menthol-sensitive Vglut $3{ }^{\text {lineage }}$ neurons is blocked by TTX (Fig. 6A). A 1 min application of TTX $(0.3$ or $1 \mu \mathrm{M})$ abolished action potential firing in menthol-sensitive Vglut $3^{\text {lineage }}$ neurons (Fig. 6B). On the other hand, $1 \mu \mathrm{M}$ TTX abolished action potential firing in only 3/11 mentholinsensitive Vglut $3^{\text {lineage }}$ neurons. The inhibitory effect of TTX on action potential firing was significantly greater in mentholsensitive neurons compared with mentholinsensitive neurons $(p=0.0053$, unpaired Student's $t$ test; Fig. $6 B$ ). Thus, these results demonstrate that menthol-sensitive and -insensitive Vglut3 ${ }^{\text {lineage }}$ neurons have functionally distinct complements of $\mathrm{Na}_{\mathrm{V}}$ subunits, with TTX-sensitive channels driving action potential firing in the former and TTX-resistant channels playing a major role in spike firing in the latter.

We next aimed to dissect the specific contributions of individual TTX-sensitive $\mathrm{Na}_{\mathrm{V}}$ subunits to action potential firing in menthol-sensitive Vglut $3^{\text {lineage }}$ neurons. A metabolite of TTX, 4,9-anhydro-TTX (AH-TTX), has been reported to selectively block $\mathrm{Na}_{\mathrm{V}} 1.6$ channels (Rosker et al., 2007); however, its effect on $\mathrm{Na}_{\mathrm{V}} 1.1$ channels was not examined. Accordingly, we analyzed inhibition by AH-TTX of sodium currents in HEK cells stably transfected with human $\mathrm{Na}_{\mathrm{V}} 1.1$ channels (Kahlig et al., 2010). The average peak amplitude for $\mathrm{Na}_{\mathrm{V}} 1.1$ currents recorded from this cell line was $-2499 \pm 1499 \mathrm{pA}(n=15)$. The dose-response curve obtained showed an apparent $\mathrm{IC}_{50}$ of $120.7 \mathrm{~nm}(n=3-5$ observations per concentration; Fig. $6 C$ ). Indeed, there was notable block of $\mathrm{Na}_{\mathrm{V}} 1.1$ currents by $200 \mathrm{~nm} \mathrm{AH-TTX} \mathrm{(Fig.} \mathrm{6D),}$ which is within the range of concentrations typically used to block $\mathrm{Na}_{\mathrm{V}} 1.6$ (100-300 nM; Rosker et al., 2007; Hargus et al., 2013; Barker et al., 2017). Thus, we were unable to use this reagent to examine a specific role for $\mathrm{Na}_{\mathrm{V}} 1.6$ channels in action potential firing in menthol-sensitive Vglut $3^{\text {lineage }}$ neurons. 
A role for $\mathrm{Na}_{\mathrm{v}} 1.1$ in menthol-sensitive Vglut $3^{\text {lineage }}$ neurons

The TTX-sensitive channels $\mathrm{Na}_{\mathrm{V}} 1.1$ and $\mathrm{Na}_{\mathrm{V}} 1.7$ are both expressed in adult DRG neurons and have been implicated in various forms of pain processing (Cummins et al., 2004; Nassar et al., 2004; Osteen et al., 2016). Whether or not they function in small-diameter Vglut3 lineage DRG neurons has yet to be determined. We therefore investigated the contribution of these subunits to action potential firing in menthol-sensitive neurons.

We first tested ICA 121431, an inhibitor of the $\mathrm{Na}_{\mathrm{V}} 1.1$ and $\mathrm{Na}_{\mathrm{V}} 1.3$ channels (Fig. $7 A, B$ ). $\mathrm{Na}_{\mathrm{V}} 1.3$ is expressed at only low levels in uninjured adult rat, mouse and human DRGs (Waxman et al., 1994; Felts et al., 1997; He et al., 2010; Usoskin et al., 2015; Chang et al., 2018). Thus, we used ICA 121431 as a blocker of $\mathrm{Na}_{\mathrm{V}} 1.1$ channels in adult mouse DRG preparations (McCormack et al., 2013). Application of $500 \mathrm{~nm}$ ICA 121431 drastically reduced action potential firing in menthol-sensitive Vglut3 lineage neurons (baseline: $37.1 \pm 7.8 \mathrm{~Hz}$, post-ICA 121431: $4.6 \pm 4.9 \mathrm{~Hz} ; n=11$; Fig. $7 B$ ). Action potential firing was also reduced in a subset of menthol-insensitive Vglut 3 lineage neurons $(5.5 \pm 4.4-2.0 \pm 1.9 \mathrm{~Hz} ; n=8)$. Like TTX, however, the effect of ICA 121431 was significantly greater in menthol-sensitive compared with menthol-insensitive neurons ( $p=0.0363$; Fig. $7 B)$. The specificity of ICA 121431's block of $\mathrm{Na}_{\mathrm{V}} 1.1$ currents was confirmed by testing inhibition of recombinant $\mathrm{Na}_{\mathrm{V}} 1.1$, $\mathrm{Na}_{\mathrm{V}} 1.6$, and $\mathrm{Na}_{\mathrm{V}} 1.7$ mediated currents $\left(\mathrm{IC}_{50}=25.2 \mathrm{nM}, 2.7 \mu \mathrm{M}\right.$, and $2.8 \mu \mathrm{M}$ respectively, $n=4-6$ observations per concentration; Fig. $7 C, D$ ). The average peak currents recorded for $\mathrm{Na}_{\mathrm{V}} 1.6$ and $\mathrm{Na}_{\mathrm{V}} 1.7$ channels were $-1545 \pm 1134 \mathrm{pA}$ and $-1147 \pm 1391 \mathrm{pA}(n=6$ and $n=9$, respectively).

We next investigated the contribution of $\mathrm{Na}_{\mathrm{V}} 1.7$ channels to action potential firing in menthol-sensitive neurons using PF 05089771 (25 nM; Alexandrou et al., 2016; Theile et al., 2016), a selective blocker of this channel. PF 05089771 had little effect on mean firing rates in menthol-sensitive Vglut $3{ }^{\text {lineage }}$ neurons (Fig. $8 A, B)$. Moreover, when cells were analyzed as a percentage of control firing, the effects of PF 05089771 did not differ between menthol-sensitive and menthol-insensitive neurons. A dose-response curve performed in HEK cells transiently transfected with recombinant $\mathrm{Na}_{\mathrm{V}} 1.7$ showed an apparent $\mathrm{IC}_{50}$ of $\mathrm{PF}$ 05089771 for inhibition of $\mathrm{Na}_{\mathrm{V}} 1.7$ of $10.7 \mathrm{nM}(n=4-5$ observations per concentration; Fig. $8 C$ ), consistent with published values (Alexandrou et al., 2016; Theile et al., 2016). Thus, at the concentration used in this study, PF 05089771 blocked $\sim 70 \%$ of the $\mathrm{Na}_{\mathrm{V}} 1.7$-mediated current (Fig. $8 D$ ). We also tested the spider venom toxin Pn3a (300 nM), a structurally unrelated $\mathrm{Na}_{\mathrm{V}} 1.7$ antagonist whose mechanism is distinct
B

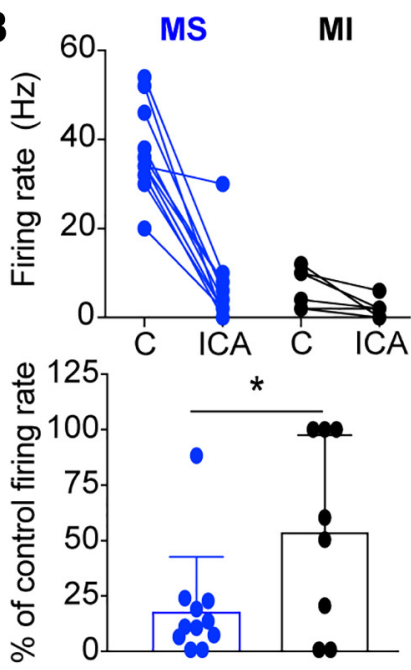

D

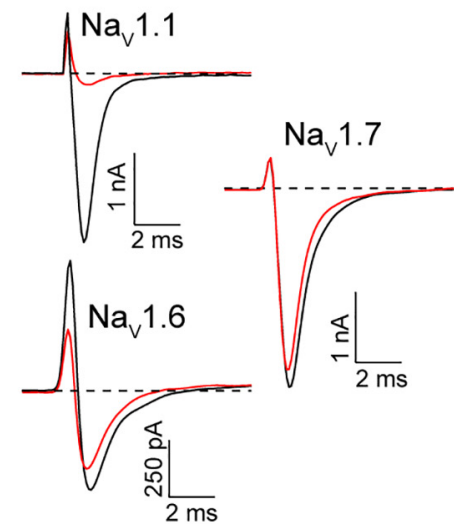

Figure 7. A critical role for $\mathrm{Na}_{\mathrm{v}} 1.1$ channels in action potential firing by menthol-sensitive Vglut 3 lineage DRG neurons. $\boldsymbol{A}$, Representative current-clamp traces from menthol-sensitive (MS; top, blue) and -insensitive (Ml; bottom, black) Vglut3 ${ }^{\text {lineage }}$ DRG (left) and after (right) a 1 min application of ICA 121431 (500 nM). B, Top, Quantification of firing rates before and curve quantifying inhibition of recombinant human $\mathrm{Na}_{v} 1.1$ (black circles), $\mathrm{Na}_{v} 1.6$ (green triangles), and $\mathrm{Na}_{v} 1.7$ (magenta dia monds) by ICA 121431. The apparent $\mathrm{IC}_{50}$ for $\mathrm{Na}_{\mathrm{V}} 1.1$ is indicated by a red dashed line. The concentration of ICA 121431 used in this study is indicated by a black dashed line. $\boldsymbol{D}$, Representative whole-cell voltage-clamp traces of $\mathrm{Na}_{y} 1.1, \mathrm{Na}_{\mathrm{y}} 1.6$ and $\mathrm{Na}_{\mathrm{v}} 1.7$ currents elicited from HEK293 cells before (black trace) and after (red trace) application of $500 \mathrm{~nm} \mathrm{ICA} \mathrm{121431.} \mathrm{Red} \mathrm{inhibitory} \mathrm{sign} \mathrm{indicates}$ the inhibition of denoted $\mathrm{Na}_{\mathrm{v}}$ subunits by the blocker. ${ }^{*} p<0.05$.

from that of PF 05089771 (Deuis et al., 2017). Consistent with results obtained using PF 05089771, Pn3a had no effect on action potential firing in menthol-sensitive neurons (control: $38.7 \pm 5.0 \mathrm{~Hz}$, after Pn3a perfusion: $34.0 \pm 4.0 \mathrm{~Hz}, n=3$; Fig. $8 B)$. Together, these results demonstrate that action potential firing in menthol-sensitive Vglut $3^{\text {lineage }}$ neurons depends upon TTX-sensitive $\mathrm{Na}_{\mathrm{V}} \mathrm{s}$ including $\mathrm{Na}_{\mathrm{V}} 1.1$.

$\mathrm{Na}_{\mathrm{V}} 1.1$ channels are critical determinants of entry into slow inactivation in menthol-sensitive Vglut $3^{\text {lineage }}$ neurons As $\mathrm{Na}_{\mathrm{V}}$ currents in menthol-sensitive Vglut $3^{\text {lineage }}$ neurons are resistant slow inactivation, we next asked whether this biophysical feature depended upon the activity of $\mathrm{Na}_{\mathrm{V}} 1.1$ channels. To accomplish this, we analyzed rates of entry into, and recovery from, slow inactivation in menthol-sensitive Vglut $3^{\text {lineage }}$ neurons in the presence of $500 \mathrm{~nm}$ ICA 121431. Analysis of whole-cell currents found that the ICA-sensitive component was $38.3 \pm$ $20.2 \%$ of the total $\mathrm{Na}_{\mathrm{V}}$ current in these neurons (Fig. $9 A, B$ ). In 
A
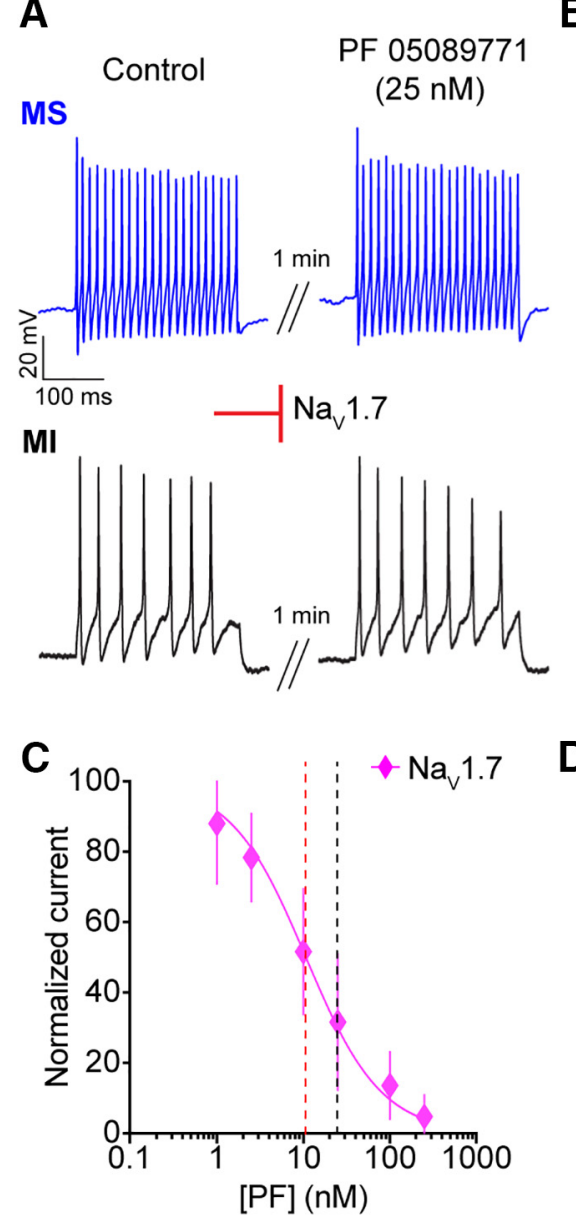

B

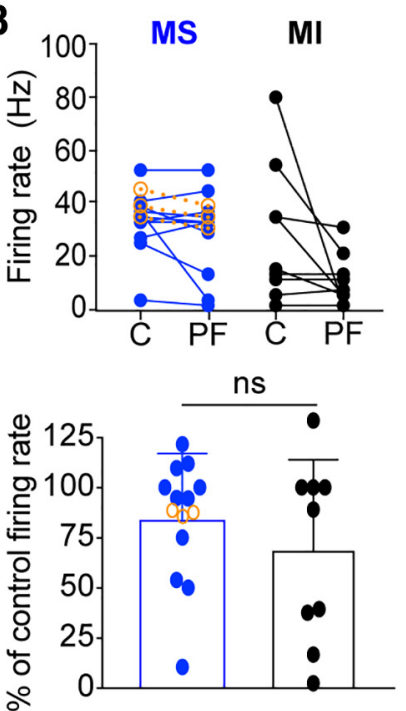

D

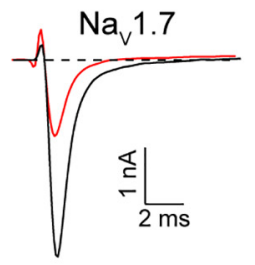

Figure 8. $\quad \mathrm{Na}_{\mathrm{v}} 1.7$ channels do not contribute to action potential firing in small-diameter Vglut $3{ }^{\text {lineage }}$ DRG neurons. $\boldsymbol{A}, \mathrm{Repre}-$ sentative current-clamp traces from menthol-sensitive (MS; top, blue) and -insensitive (Ml; bottom, black) Vglut 3 lineage DRG neurons before (left) and after (right) a 1 min application of PF 05089771 ( 25 nM). B, Top, Quantification of firing rates before and after PF 05089771 application ( $n=11$ MS neurons, $n=9$ MI neurons) or Pn3a ( $300 \mathrm{~nm}$, orange symbols in $F ; n=3$ MS neurons). Lines connecting symbols indicate paired observations. Bottom, Quantification of the percentage of control firing rate that remained following PF 05089771 application. C, A dose-response curve measuring inhibition of recombinant human $\mathrm{Na}_{\mathrm{y}} 1.7 \mathrm{chan}-$ nels by PF 05089771 . The apparent IC $_{50}$ is indicated by a red dashed line. The concentration of PF 05089771 used in this study is indicated by a black dashed line. $\boldsymbol{D}$, Representative whole-cell voltage-clamp traces of $\mathrm{Na}_{\mathrm{v}} 1.7$ currents elicited from HEK293 cells before (black trace) and after (red trace) application of $25 \mathrm{~nm}$ PF 05089771 . Red inhibitory sign indicates the inhibition of denoted $\mathrm{Na}_{v}$ subunits by the blocker. Significance was determined by unpaired Student's $t$ tests. ns $=$ not significant.

line with $\mathrm{Na}_{\mathrm{V}} 1.1$ channels being critical to the excitability of menthol-sensitive DRG neurons, we found the rate of entry into slow inactivation drastically increased in the presence of ICA 121431. The previously observed rate of $1485 \mathrm{~ms}$ fell to $327.7 \mathrm{~ms}$ when $\mathrm{Na}_{\mathrm{V}} 1.1$ channels were blocked (Fig. $9 C ; n=10$ ). Conversely, the average weighted time constant of recovery from slow inactivation more than doubled [without ICA $121431: 311.2 \mathrm{~ms}$ vs with ICA 121431: $686.4 \mathrm{~ms}\left(\tau_{1}=725.1 \mathrm{~ms}, \tau_{2}=59.8 \mathrm{~ms}\right), n=$ 6; Fig. $9 D$ ]. Linear regression analysis showed a significant correlation between the magnitude of the ICA-sensitive current and the rate of entry into slow inactivation $\left(r^{2}=0.43, p=0.04, n=\right.$ 10; Fig. $9 E$ ). On the other hand, the amplitude of the ICAsensitive current did not correlate with the rate of recovery from slow inactivation $\left(r^{2}=0.37, p=0.20, n=6\right.$; Fig. $\left.9 F\right)$. These data demonstrate a new role for $\mathrm{Na}_{\mathrm{V}} 1.1$ in setting the rate of $\mathrm{Na}_{\mathrm{V}}$ current entry into slow inactivation in sensory neurons. Collectively, our results support a role for $\mathrm{Na}_{\mathrm{V}} 1.1$ channels as key mediators of excitability in menthol-sensitive Vglut ${ }^{\text {lineage }}$ neurons.

\section{Discussion}

Small-diameter Vglut ${ }^{\text {lineage }}$ DRG neurons are a heterogeneous population that encode distinct somatic senses. This study reveals two important findings about the functional heterogeneity in such neurons. First, menthol-sensitive Vglut3 ${ }^{\text {lineage }}$ DRG neurons possess a unique excitability profile, which allows them to maintain prolonged spike discharges. Second, TTX-sensitive $\mathrm{Na}_{V} \mathrm{~s}$ mediate action potential firing in these sensory neurons, with a notable contribution of $\mathrm{Na}_{\mathrm{V}} 1.1$. We propose that cation influx through TRPM8 ion channels produces an excitatory drive that activates $\mathrm{Na}_{\mathrm{V}} 1.1$ ion channels at room temperature. Once activated, these channels cycle through open and fast-inactivated states, with the majority of channels bypassing long-lived slow inactivated states. This is likely attributable to unique features of $\mathrm{Na}_{\mathrm{V}} 1.1$-containing macromolecular complexes in mentholsensitive neurons, including association with auxiliary proteins or posttranslational modifications (Aman and Raman, 2007), with the end result being continuous action potential firing (Fig. 10). Thus, menthol-sensitive Vglut $3{ }^{\text {lineage }}$ DRG neurons represent a highly excitable population of small-diameter sensory neurons in which action potential firing depends upon TTX-sensitive $\mathrm{Na}_{\mathrm{V}}$ complexes.

Prior work has focused on the role of potassium channels as excitability breaks in TRPM8-expressing sensory neurons. A molecular profiling study identified the TASK-3 leak potassium channel as highly enriched in TRPM8 ${ }^{+}$DRG neurons and suggested that inhibition of this channel decreases cold activation thresholds (Morenilla-Palao et al., 2014). There was only a modest effect, however, of TASK-3 genetic deletion on intrinsic excitability. $\mathrm{H}$-current $\left(I_{\mathrm{h}}\right)$, a conductance mediated by hyperpolarization-activated cyclic nucleotide-gated (HCN) channels, is reportedly pronounced in cold-activated sensory neurons (Viana et al., 2002; Orio et al., 2009). Furthermore, genetic deletion of $\mathrm{Hcn} 1$ converts firing patterns in cold-sensing optic nerve fibers from regular to burst spiking (Orio et al., 2012). Consistent with previous studies, we observed a prominent sag ratio, a current-clamp readout of $I_{\mathrm{h}}$, in menthol-sensitive Vglut $3^{\text {lineage }}$ neurons; however, our study revealed no difference in sag ratio between menthol-sensitive and -insensitive Vglut 3 lineage neurons. Thus, TASK-3 and HCN channels, though important for cold detection, are unlikely to mediate the differences in intrinsic excitability between these two populations. Future studies are needed to determine whether other potassium conductances, such as those mediated by $\mathrm{K}_{\mathrm{v}} 1$ (Madrid et al., 2009; González et al., 2017a,b), contribute to differences in intrinsic excitability between menthol-sensitive and -insensitive DRG neurons. 

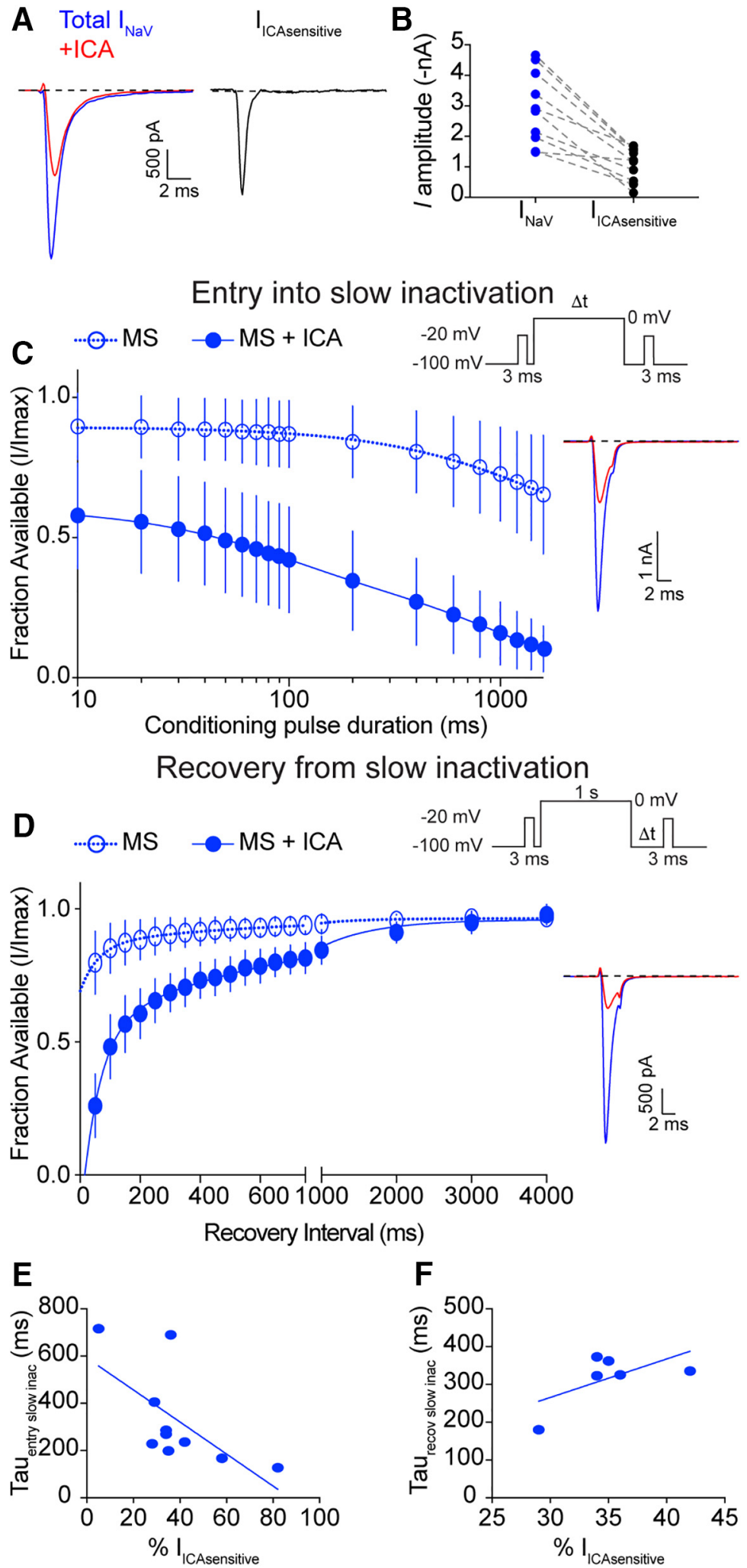

Figure 9. $\mathrm{Na}_{\mathrm{v}} 1.1$ channels determine entry into slow inactivation rates in menthol-sensitive Vglut3 ${ }^{\text {lineage }}$ neurons. $\boldsymbol{A}$, Representative whole-cell voltage-clamp traces of currents elicited from a MS neuron in the before (blue trace) and after application of $500 \mathrm{~nm}$ ICA 121431 (red trace). The subtracted $\mathrm{Na}_{\mathrm{v}} 1$ 1-1-mediated current is shown in black. $\boldsymbol{B}$, Quantification of peak $\mathrm{Na}_{\mathrm{V}}$ current amplitude before (blue circles) and after ICA 121431 application (black circles). Gray dashed lines indicated paired observations. $\boldsymbol{C}$, Quantification of entry into slow inactivation for MS Vglut3 ${ }^{\text {lineage }}$ DRG neurons during blockade of $\mathrm{Na}_{\mathrm{v}} 1.1$ channels by ICA 121431 (filled circles, blue lines). Data for MS neurons from Figure $4 A$ is shown for comparison (clear circles, dashed lines). The current elicited following a conditioning pulse to $0 \mathrm{mV}$ is normalized to the current elicited during an initial test step and plotted against the duration of the conditioning pulse. Lines show exponential fits to the data. Top right, Voltage protocol used to measure $\mathrm{Na}_{\mathrm{V}}$ entry into slow inactivation. Bottom right, Representative whole-cell voltage-clamp traces. Blue trace represents initial test step;
In addition to potassium channels, previous studies investigated TTX-resistant $\mathrm{Na}_{\mathrm{V}} \mathrm{s}$ in menthol-sensitive DRG neurons. $\mathrm{Na}_{\mathrm{V}} 1.8$ is found in $\sim 90 \%$ of smalldiameter DRG neurons (Shields et al., 2012) and has been implicated in menthol-sensitized cold responses (Zimmermann et al., 2007). However, $\mathrm{Na}_{\mathrm{V}} 1.8$ null mice show normal physiological and behavioral responses to cold (Luiz et al., 2019). A recent study identified a subpopulation of DRG neurons that are both Vglut $3^{\text {lineage }}$ and $\mathrm{Na}_{\mathrm{V}} 1.8^{\text {lineage }}$ (Patil et al., 2018). These neurons possess properties to similar the menthol-sensitive neurons analyzed in the present work, including fast action potential durations, insensitivity to capsaicin, and small somata. Moreover, $\mathrm{Na}_{\mathrm{V}} 1.9$, the other TTX-resistant $\mathrm{Na}_{\mathrm{V}}$ isoform, was reported to be expressed in nociceptors that respond to cooling, as well as contribute to pain perception in response to noxious cold (Lolignier et al., 2015). In that study, however, $\mathrm{Na}_{\mathrm{V}} 1.9$ mRNA coexpressed with only $\sim 20 \%$ of TRPM8 ${ }^{+}$DRG neurons. The proportion of adult menthol-sensitive neurons that express functional $\mathrm{Na}_{\mathrm{V}} 1.8$ or $\mathrm{Na}_{\mathrm{V}} 1.9$ protein is unknown; nonetheless, our pharmacological studies indicate that TTX-resistant $\mathrm{Na}_{\mathrm{V}} \mathrm{s}$ do not drive action potential firing in menthol-sensitive neurons under our experimental conditions.

Instead, we provide evidence that functionally distinct $\mathrm{Na}_{\mathrm{V}} \mathrm{s}$ contribute to the different excitability profiles of menthol-sensitive and -insensitive Vglut 3 lineage DRG neurons. Although multiplex in situ hybridization data showed widespread expression of several $\mathrm{Na}_{\mathrm{V}}$ transcripts, our pharmacological analysis revealed a more restricted functional contribution, with $\mathrm{Na}_{\mathrm{V}} 1.1$ comprising over one-third of the total $\mathrm{Na}_{\mathrm{V}}$ current and mediating most ac-

\footnotetext{
$\leftarrow$

red trace represents test pulses given after a $200 \mathrm{~ms}$ conditioning step. D, Left, Same as C except Quantification represents recovery from slow inactivation kinetics. Data for MS neurons from Figure $A B$ is shown for comparison (clear circles, dashed lines). Recovery during the second test step is normalized to the current during the initial test step and plotted against the recovery interval. Lines show double-exponential fits to the data. MS neurons + ICA: $\tau_{1}=725.1 \mathrm{~ms}, \tau_{2}=59.8 \mathrm{~ms}, n=$ 6. Top right, Voltage protocol used to measure $\mathrm{Na}_{\mathrm{v}}$ recovery from slow inactivation. Bottom right, Representative wholecell voltage-clamp trace of current elicited from a MS neuron in the presence of ICA 121431. Blue trace represents initial test step; red trace represents pulse given $50 \mathrm{~ms}$ after the conditioning step. $\boldsymbol{E}$, Individual entry into slow inactivation rates for MS neurons plotted against the percentage of the total $\mathrm{Na}_{\mathrm{V}}$ current that was sensitive to ICA 121431; $r^{2}=0.43, p=0.04$. $\boldsymbol{F}$, Same as $\boldsymbol{E}$ but individual recovery from slow inactivation rates are plotted; $r^{2}=0.37, p=0.20$.
} 


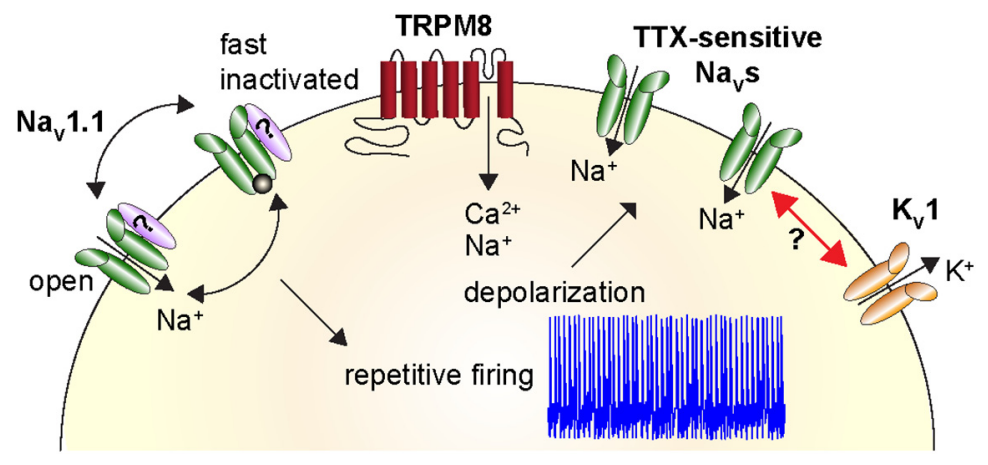

Figure 10. Proposed model demonstrating heightened excitability of menthol-sensitive Vglut $3{ }^{\text {lineage }}$ DRG neurons. Activation of TRPM8 ion channels (red) causes an influx of cations that depolarizes the neuron. This leads to activation of TTX-sensitive $\mathrm{Na}_{\mathrm{v}} \mathrm{S}$, including $\mathrm{Na}_{\mathrm{v}} 1.1$ channels (green), and subsequent action potential firing. Repetitive firing is achieved by NaV1.1 channels cycling through open and fast-inactivated states, without being sequestered into long-lived slow inactivated states. This may be facilitated by association with auxiliary proteins (purple). $\mathrm{Na}_{\mathrm{y}}$ complexes in menthol-sensitive Vglut ${ }^{3}{ }^{\text {lineage }} \mathrm{DRG}$ neurons could function to oppose a strong hyperpolarizing conductance mediated by $\mathrm{K}_{\mathrm{v}} 1$ potassium channels (orange).

tion potential firing in menthol-sensitive Vglut $3^{\text {lineage }}$ DRG neurons. Conversely, TTX-resistant channels dominated in menthol-insensitive neurons. In DRG, $\mathrm{Na}_{\mathrm{V}} 1.1$ is reported to be predominantly localized to medium-diameter neurons that mediate mechanical pain (Osteen et al., 2016). Interestingly, that study showed that $\sim 40 \%$ of trigeminal neurons that express functional $\mathrm{Na}_{\mathrm{V}} 1.1$ channels also exhibit menthol-evoked calcium transients. Our study extends these findings by demonstrating that action potential firing in menthol-sensitive Vglut 3 lineage DRG neurons is dependent upon TTX-sensitive $\mathrm{Na}_{\mathrm{V}} \mathrm{s}$, with the $\mathrm{Na}_{\mathrm{V}} 1.1 / \mathrm{Na}_{\mathrm{V}} 1.3$ antagonist ICA 121431 dramatically reducing firing rates. Furthermore, although TTX-sensitive $\mathrm{Na}_{\mathrm{V}} 1.7$ channels are important to the function of small-diameter nociceptors and pain signaling (Cox et al., 2006; Minett et al., 2012; Yang et al., 2018), these channels are likely inactivated at the resting membrane potential of menthol-sensitive neurons. Indeed, the $\mathrm{V}_{1 / 2}$ of inactivation of $\mathrm{Na}_{\mathrm{V}} 1.7$ is $\sim-75 \mathrm{mV}$ (Alexandrou et al., 2016). Conversely, the $\mathrm{V}_{1 / 2}$ inactivation of $\mathrm{Na}_{\mathrm{V}} 1.1$ is $\sim-17 \mathrm{mV}$ (Aman et al., 2009), a membrane potential that is much more depolarized than the resting potential of menthol-sensitive Vglut $3^{\text {lineage }}$ DRG neurons in our study. Thus, we have identified a new role for TTX-sensitive $\mathrm{Na}_{\mathrm{V}} 1.1$ channels in action potential firing in small-diameter DRG neurons.

$\mathrm{Na}_{\mathrm{V}} 1.1$ channels promote excitability and high-frequency firing in several neuronal populations. In mouse models of irritable bowel syndrome and chronic visceral hypersensitivity, $\mathrm{Na}_{\mathrm{V}} 1.1$ is functionally upregulated, leading to hyperexcitability of mechanosensory fibers innervating the colon (Osteen et al., 2016; Salvatierra et al., 2018). Moreover, mutations in $\mathrm{Na}_{\mathrm{V}} 1.1$ are most frequently associated with inherited forms of epilepsy, including Dravet syndrome (Catterall et al., 2010). In this disorder, loss of $\mathrm{Na}_{\mathrm{V}} 1.1$ in hippocampal interneurons leads to reduced sodium current and attenuated action potential firing (Yu et al., 2006), resulting in disinhibition of hippocampal circuits that causes seizures (Oakley et al., 2013). To our knowledge, our results provide the first functional evidence for $\mathrm{Na}_{\mathrm{V}} 1$.1-dependent action potential firing in small-diameter somatosensory neurons.

Our data also indicate that the biophysical properties of $\mathrm{Na}_{\mathrm{V}} 1$ 1-1-containing channel complexes could explain the heightened excitability of menthol-sensitive DRG neurons. $\mathrm{Na}_{\mathrm{V}}$ currents in these neurons entered into slow inactivation much more slowly than what has been reported for other DRG populations (Blair and Bean, 2003), with a time constant of $\sim 1.5 \mathrm{~s}$ (Fig. $4 A$ ).
This contrasts with capsaicin-sensitive nociceptors and $\mathrm{IB}_{4}{ }^{+}$DRG neurons, where slow inactivation of TTX-resistant $\mathrm{Na}_{\mathrm{V}} \mathrm{s}$ is reported to produce action potential adaptation in response to sustained depolarization (Blair and Bean, 2003; Choi et al., 2007). Importantly, application of ICA 121431 drastically enhanced the rate of entry into slow inactivation in menthol-sensitive DRG neurons (Fig. 9C). Thus, the resistance of $\mathrm{Na}_{\mathrm{V}} 1.1$ currents to slow inactivation could be a mechanism by which menthol-sensitive neurons sustain action potential firing for extended periods of time.

Previous studies have reported that $\mathrm{Na}_{\mathrm{V}} 1.1$ channels are subject to usedependent inactivation at high firing frequencies (Spampanato et al., 2001). It is therefore possible that in mentholsensitive neurons, $\mathrm{Na}_{\mathrm{V}} 1.1 \alpha$ subunits associate with auxiliary proteins that destabilize inactivated states, such as the $\beta 4$ subunit (Aman et al., 2009). Moreover, because of the lack of selective pharmacological tools, we were unable to test the contribution of $\mathrm{Na}_{\mathrm{V}} 1.6$ channels to action potential firing in small-diameter Vglut 3 lineage DRG neurons. It has been hypothesized, however, that synergistic activity of $\mathrm{Na}_{\mathrm{V}} 1.1$ and $\mathrm{Na}_{\mathrm{V}} 1.6$ is important for overcoming the high action potential threshold set by voltagegated potassium channels of the $\mathrm{K}_{\mathrm{V}} 1$ family in pyramidal cells and GABAergic interneurons (Lorincz and Nusser, 2008). $K_{V} 1$ channels are also expressed in TRPM $8^{+}$trigeminal neurons, where they are proposed to determine thermal excitability (Madrid et al., 2009). We cannot rule out the possibility that action potential firing patterns in menthol-sensitive Vglut $3{ }^{\text {lineage }} \mathrm{DRG}$ neurons are tuned by the concerted actions of $\mathrm{Na}_{\mathrm{V}} 1.1$ and $\mathrm{Na}_{\mathrm{V}} 1.6$ channels that counterbalance an opposing $\mathrm{K}_{\mathrm{v}} 1$ conductance, thus regulating the responsiveness of these neurons (Fig. 10).

The finding that menthol-sensitive neurons are a subset of Vglut ${ }^{\text {lineage }}$ neurons raises the possibility that Vglut3 protein plays a role in synaptic transmission from TRPM8-expressing DRG neurons to second order neurons in the spinal cord. In contrast to this model, Vglut $3^{-1-}$ mice are reported to have normal responses to cold stimuli, indicating that Vglut3 protein is not required for TRPM8-dependent behaviors in mice (Draxler et al., 2014). Furthermore, in sensory neurons innervating the dura and cerebral blood vessels, TRPM8 and Vglut3 protein expression do not overlap in adult mice (Ren et al., 2018). Thus, we speculate that menthol-sensitive neurons express the Slc17a8 locus during development rather than in mature DRG.

Collectively, our data indicate that, unlike many other smalldiameter DRG populations, action potential firing in mentholsensitive DRG neurons is dependent upon TTX-sensitive $\mathrm{Na}_{\mathrm{V}} \mathrm{s}$ including $\mathrm{Na}_{\mathrm{V}}$ 1.1. Genetic approaches using $\mathrm{Na}_{\mathrm{V}} 1$.1-null mutations are needed to define the exact contributions of this subunit to the function of menthol-sensitive neurons, as well as sensorydriven behaviors (Cheah et al., 2012). It also remains to be determined whether $\mathrm{Na}_{\mathrm{V}} 1.1$ channels are viable therapeutic targets for pathologies that produce cold hypersensitivity. Additionally, menthol has been used for centuries as a topical analgesic and anti-pruritic. Indeed, it has been shown that TRPM8-expressing DRG neurons are required for inhibition of itch by cooling and furthermore, that topical application of menthol inhibits chloroquine-evoked itch behaviors (Palkar et al., 2018). Thus, 
targeting TTX-sensitive $\mathrm{Na}_{\mathrm{V}} 1.1$ channels in menthol-sensitive DRG neurons might prove to be a new direction for the treatment of various sensory disorders.

\section{References}

Alexandrou AJ, Brown AR, Chapman ML, Estacion M, Turner J, Mis MA, Wilbrey A, Payne EC, Gutteridge A, Cox PJ, Doyle R, Printzenhoff D, Lin Z, Marron BE, West C, Swain NA, Storer RI, Stupple PA, Castle NA, Hounshell JA, et al. (2016) Subtype-selective small molecule inhibitors reveal a fundamental role for Nav1.7 in nociceptor electrogenesis, axonal conduction and presynaptic release. PLoS One 11:e0152405.

Aman TK, Raman IM (2007) Subunit dependence of na channel slow inactivation and open channel block in cerebellar neurons. Biophys J 92:1938-1951.

Aman TK, Grieco-Calub TM, Chen C, Rusconi R, Slat EA, Isom LL, Raman IM (2009) Regulation of persistent Na current by interactions between $\beta$ subunits of voltage-gated Na channels. J Neurosci 29:2027-2042.

Andersson DA, Chase HW, Bevan S (2004) TRPM8 activation by menthol, icilin, and cold is differentially modulated by intracellular $\mathrm{pH}$. J Neurosci 24:5364-5369.

Barker BS, Nigam A, Ottolini M, Gaykema RP, Hargus NJ, Patel MK (2017) Pro-excitatory alterations in sodium channel activity facilitate subiculum neuron hyperexcitability in temporal lobe epilepsy. Neurobiol Dis 108: 183-194.

Bautista DM, Wilson SR, Hoon MA (2014) Why we scratch an itch: the molecules, cells and circuits of itch. Nat Neurosci 17:175-182.

Black JA, Dib-Hajj S, McNabola K, Jeste S, Rizzo MA, Kocsis JD, Waxman SG (1996) Spinal sensory neurons express multiple sodium channel alphasubunit mRNAs. Brain Res Mol Brain Res 43:117-131.

Blair NT, Bean BP (2002) Roles of tetrodotoxin (TTX)-sensitive Na+ current, TTX-resistant $\mathrm{Na}+$ current, and $\mathrm{Ca}^{2+}$ current in the action potentials of nociceptive sensory neurons. J Neurosci 22:10277-10290.

Blair NT, Bean BP (2003) Role of tetrodotoxin-resistant Na+ current slow inactivation in adaptation of action potential firing in small-diameter dorsal root ganglion neurons. J Neurosci 23:10338-10350.

Catterall WA (2012) Voltage-gated sodium channels at 60: structure, function and pathophysiology. J Physiol 590:2577-2589.

Catterall WA, Kalume F, Oakley JC (2010) NaV1.1 channels and epilepsy. J Physiol 588:1849-1859.

Chang W, Berta T, Kim YH, Lee S, Lee SY, Ji RR (2018) Expression and role of voltage-gated sodium channels in human dorsal root ganglion neurons with special focus on Nav1.7, species differences, and regulation by paclitaxel. Neurosci Bull 34:4-12.

Cheah CS, Yu FH, Westenbroek RE, Kalume FK, Oakley JC, Potter GB, Rubenstein JL, Catterall WA (2012) Specific deletion of NaV1.1 sodium channels in inhibitory interneurons causes seizures and premature death in a mouse model of Dravet syndrome. Proc Natl Acad Sci U S A 109: $14646-14651$.

Choi JS, Dib-Hajj SD, Waxman SG (2007) Differential slow inactivation and use-dependent inhibition of Nav1.8 channels contribute to distinct firing properties in IB4+ and IB4- DRG neurons. J Neurophysiol 97: $1258-1265$

Cox JJ, Reimann F, Nicholas AK, Thornton G, Roberts E, Springell K, Karbani G, Jafri H, Mannan J, Raashid Y, Al-Gazali L, Hamamy H, Valente EM, Gorman S, Williams R, McHale DP, Wood JN, Gribble FM, Woods CG (2006) An SCN9A channelopathy causes congenital inability to experience pain. Nature 444:894-898.

Cummins TR, Dib-Hajj SD, Waxman SG (2004) Electrophysiological properties of mutant Nav1.7 sodium channels in a painful inherited neuropathy. J Neurosci 24:8232-8236.

Deuis JR, Dekan Z, Wingerd JS, Smith JJ, Munasinghe NR, Bhola RF, Imlach WL, Herzig V, Armstrong DA, Rosengren KJ, Bosmans F, Waxman SG, Dib-Hajj SD, Escoubas P, Minett MS, Christie MJ, King GF, Alewood PF, Lewis RJ, Wood JN, et al. (2017) Pharmacological characterisation of the highly NaV1.7 selective spider venom peptide Pn3a. Sci Rep 7:40883.

Dhaka A, Earley TJ, Watson J, Patapoutian A (2008) Visualizing cold spots: TRPM8-expressing sensory neurons and their projections. J Neurosci 28:566-575.

Djouhri L, Bleazard L, Lawson SN (1998) Association of somatic action potential shape with sensory receptive properties in guinea-pig dorsal root ganglion neurones. J Physiol 513:857-872.

Draxler P, Honsek SD, Forsthuber L, Hadschieff V, Sandkühler J (2014)
VGluT3(+) primary afferents play distinct roles in mechanical and cold hypersensitivity depending on pain etiology. J Neurosci 34:12015-12028.

Dubin AE, Patapoutian A (2010) Nociceptors: the sensors of the pain pathway. J Clin Invest 120:3760-3772.

Felts PA, Yokoyama S, Dib-Hajj S, Black JA, Waxman SG (1997) Sodium channel alpha-subunit mRNAs I, II, III, NaG, Na6 and hNE (PN1): different expression patterns in developing rat nervous system. Brain Res Mol Brain Res 45:71-82.

Fujita F, Uchida K, Takaishi M, Sokabe T, Tominaga M (2013) Ambient temperature affects the temperature threshold for TRPM8 activation through interaction of phosphatidylinositol 4,5-bisphosphate. J Neurosci 33:6154-6159.

González A, Herrera G, Ugarte G, Restrepo C, Piña R, Pertusa M, Orio P, Madrid R (2017a) IKD current in cold transduction and damagetriggered cold hypersensitivity. Adv Exp Med Biol 1015:265-277.

González A, Ugarte G, Restrepo C, Herrera G, Piña R, Gómez-Sanchez JA, Pertusa M, Orio P, Madrid R (2017b) Role of the excitability brake potassium current IKD in cold allodynia induced by chronic peripheral nerve injury. J Neurosci 37:3109-3126.

Grimes WN, Seal RP, Oesch N, Edwards RH, Diamond JS (2011) Genetic targeting and physiological features of VGLUT3+ amacrine cells. Vis Neurosci 28:381-392.

Hargus NJ, Nigam A, Bertram EH 3rd, Patel MK (2013) Evidence for a role of Nav1.6 in facilitating increases in neuronal hyperexcitability during epileptogenesis. J Neurophysiol 110:1144-1157.

He XH, Zang Y, Chen X, Pang RP, Xu JT, Zhou X, Wei XH, Li YY, Xin WJ, Qin ZH, Liu XG (2010) TNF-alpha contributes to up-regulation of Nav1.3 and Nav1.8 in DRG neurons following motor fiber injury. Pain 151: 266-279.

Ho C, O'Leary ME (2011) Single-cell analysis of sodium channel expression in dorsal root ganglion neurons. Mol Cell Neurosci 46:159-166.

Jankowski MP, Rau KK, Koerber HR (2017) Cutaneous TRPM8-expressing sensory afferents are a small population of neurons with unique firing properties. Physiol Rep 5:e13234.

Kahlig KM, Saridey SK, Kaja A, Daniels MA, George AL Jr, Wilson MH (2010) Multiplexed transposon-mediated stable gene transfer in human cells. Proc Natl Acad Sci U S A 107:1343-1348.

Karashima Y, Damann N, Prenen J, Talavera K, Segal A, Voets T, Nilius B (2007) Bimodal action of menthol on the transient receptor potential channel TRPA1. J Neurosci 27:9874-9884.

Knowlton WM, Daniels RL, Palkar R, McCoy DD, McKemy DD (2011) Pharmacological blockade of TRPM8 ion channels alters cold and cold pain responses in mice. PLoS One 6:e25894.

Kress GJ, Dowling MJ, Meeks JP, Mennerick S (2008) High threshold, proximal initiation, and slow conduction velocity of action potentials in dentate granule neuron mossy fibers. J Neurophysiol 100:281-291.

Liljencrantz J, Olausson H (2014) Tactile C fibers and their contributions to pleasant sensations and to tactile allodynia. Front Behav Neurosci 8:37.

Liu PW, Blair NT, Bean BP (2017) Action potential broadening in capsaicin-sensitive DRG neurons from frequency-dependent reduction of Kv3 current. J Neurosci 37:9705-9714.

Lolignier S, Bonnet C, Gaudioso C, Noël J, Ruel J, Amsalem M, Ferrier J, Rodat-Despoix L, Bouvier V, Aissouni Y, Prival L, Chapuy E, Padilla F, Eschalier A, Delmas P, Busserolles J (2015) The Nav1.9 channel is a key determinant of cold pain sensation and cold allodynia. Cell Rep 11: 1067-1078.

Lorincz A, Nusser Z (2008) Cell-type-dependent molecular composition of the axon initial segment. J Neurosci 28:14329-14340.

Lou S, Duan B, Vong L, Lowell BB, Ma Q (2013) Runx1 controls terminal morphology and mechanosensitivity of VGLUT3-expressing C-mechanoreceptors. J Neurosci 33:870-882.

Luiz AP, MacDonald DI, Santana-Varela S, Millet Q, Sikandar S, Wood JN, Emery EC (2019) Cold sensing by NaV1.8-positive and NaV1.8negative sensory neurons. Proc Natl Acad Sci U S A 116:3811-3816.

Madisen L, Zwingman TA, Sunkin SM, Oh SW, Zariwala HA, Gu H, Ng LL, Palmiter RD, Hawrylycz MJ, Jones AR, Lein ES, Zeng H (2010) A robust and high-throughput cre reporting and characterization system for the whole mouse brain. Nat Neurosci 13:133-140.

Madrid R, de la Peña E, Donovan-Rodriguez T, Belmonte C, Viana F (2009) Variable threshold of trigeminal cold-thermosensitive neurons is determined by a balance between TRPM8 and Kv1 potassium channels. J Neurosci 29:3120-3131. 
McCormack K, Santos S, Chapman ML, Krafte DS, Marron BE, West CW, Krambis MJ, Antonio BM, Zellmer SG, Printzenhoff D, Padilla KM, Lin Z, Wagoner PK, Swain NA, Stupple PA, de Groot M, Butt RP, Castle NA (2013) Voltage sensor interaction site for selective small molecule inhibitors of voltage-gated sodium channels. Proc Natl Acad Sci U S A 110:E2724-E2732.

McGlone F, Reilly D (2010) The cutaneous sensory system. Neurosci Biobehav Rev 34:148-159.

McKemy DD, Neuhausser WM, Julius D (2002) Identification of a cold receptor reveals a general role for TRP channels in thermosensation. Nature 416:52-58.

Minett MS, Nassar MA, Clark AK, Passmore G, Dickenson AH, Wang F, Malcangio M, Wood JN (2012) Distinct Nav1.7-dependent pain sensations require different sets of sensory and sympathetic neurons. Nat Commun 3:791.

Morenilla-Palao C, Luis E, Fernández-Pena C, Quintero E, Weaver JL, Bayliss DA, Viana F (2014) Ion channel profile of TRPM8 cold receptors reveals a role of TASK-3 potassium channels in thermosensation. Cell Rep 8: $1571-1582$

Nassar MA, Stirling LC, Forlani G, Baker MD, Matthews EA, Dickenson AH, Wood JN (2004) Nociceptor-specific gene deletion reveals a major role for Nav1.7 (PN1) in acute and inflammatory pain. Proc Natl Acad Sci U S A 101:12706-12711.

Oakley JC, Cho AR, Cheah CS, Scheuer T, Catterall WA (2013) Synergistic GABA-enhancing therapy against seizures in a mouse model of Dravet syndrome. J Pharmacol Exp Ther 345:215-224.

Orio P, Madrid R, de la Peña E, Parra A, Meseguer V, Bayliss DA, Belmonte C, Viana F (2009) Characteristics and physiological role of hyperpolarization activated currents in mouse cold thermoreceptors. J Physiol 587: 1961-1976.

Orio P, Parra A, Madrid R, González O, Belmonte C, Viana F (2012) Role of $I_{\mathrm{h}}$ in the firing pattern of mammalian cold thermoreceptor endings. J Neurophysiol 108:3009-3023.

Osteen JD, Herzig V, Gilchrist J, Emrick JJ, Zhang C, Wang X, Castro J, Garcia-Caraballo S, Grundy L, Rychkov GY, Weyer AD, Dekan Z, Undheim EA, Alewood P, Stucky CL, Brierley SM, Basbaum AI, Bosmans F, King GF, Julius D (2016) Selective spider toxins reveal a role for the Nav1.1 channel in mechanical pain. Nature 534:494-499.

Palkar R, Ongun S, Catich E, Li N, Borad N, Sarkisian A, McKemy DD (2018) Cooling relief of acute and chronic itch requires TRPM8 channels and neurons. J Invest Dermatol 138:1391-1399.

Park D, Dunlap K (1998) Dynamic regulation of calcium influx by G-proteins, action potential waveform, and neuronal firing frequency. J Neurosci 18:6757-6766.

Patil MJ, Hovhannisyan AH, Akopian AN (2018) Characteristics of sensory neuronal groups in CGRP-cre-ER reporter mice: comparison to Nav1.8cre, TRPV1-cre and TRPV1-GFP mouse lines. PLoS One 13:e0198601.

Pertusa M, Rivera B, González A, Ugarte G, Madrid R (2018) Critical role of the pore domain in the cold response of TRPM8 channels identified by ortholog functional comparison. J Biol Chem 293:12454-12471.

Ren L, Chang MJ, Zhang Z, Dhaka A, Guo Z, Cao YQ (2018) Quantitative analysis of mouse dural afferent neurons expressing TRPM8, VGLUT3, and NF200. Headache 58:88-101.

Ritter AM, Mendell LM (1992) Somal membrane properties of physiologically identified sensory neurons in the rat: effects of nerve growth factor. J Neurophysiol 68:2033-2041.

Rosker C, Lohberger B, Hofer D, Steinecker B, Quasthoff S, Schreibmayer W (2007) The TTX metabolite 4,9-anhydro-TTX is a highly specific blocker of the $\mathrm{Na}(\mathrm{v} 1.6)$ voltage-dependent sodium channel. Am J Physiol Cell Physiol 293:C783-C789.

Salvatierra J, Castro J, Erickson A, Li Q, Braz J, Gilchrist J, Grundy L, Rychkov GY, Deiteren A, Rais R, King GF, Slusher BS, Basbaum A, Pasricha PJ, Brierley SM, Bosmans F (2018) NaV1.1 inhibition can reduce visceral hypersensitivity. JCI Insight 3:e121000.

Schepers RJ, Ringkamp M (2010) Thermoreceptors and thermosensitive afferents. Neurosci Biobehav Rev 34:177-184.

Schneider CA, Rasband WS, Eliceiri KW (2012) NIH Image to ImageJ: 25 years of image analysis. Nat Methods 9:671-675.

Seal RP, Wang X, Guan Y, Raja SN, Woodbury CJ, Basbaum AI, Edwards RH (2009) Injury-induced mechanical hypersensitivity requires C-low threshold mechanoreceptors. Nature 462:651-655.

Shields SD, Ahn HS, Yang Y, Han C, Seal RP, Wood JN, Waxman SG, DibHajj SD (2012) Nav1.8 expression is not restricted to nociceptors in mouse peripheral nervous system. Pain 153:2017-2030.

Spampanato J, Escayg A, Meisler MH, Goldin AL (2001) Functional effects of two voltage-gated sodium channel mutations that cause generalized epilepsy with febrile seizures plus type 2. J Neurosci 21:7481-7490.

Tajino K, Hosokawa H, Maegawa S, Matsumura K, Dhaka A, Kobayashi S (2011) Cooling-sensitive TRPM8 is thermostat of skin temperature against cooling. PLoS One 6:e17504.

Takashima Y, Daniels RL, Knowlton W, Teng J, Liman ER, McKemy DD (2007) Diversity in the neural circuitry of cold sensing revealed by genetic axonal labeling of transient receptor potential melastatin 8 neurons. J Neurosci 27:14147-14157.

Theile JW, Fuller MD, Chapman ML (2016) The selective Nav1.7 inhibitor, PF-05089771, interacts equivalently with fast and slow inactivated Nav1.7 channels. Mol Pharmacol 90:540-548.

Usoskin D, Furlan A, Islam S, Abdo H, Lönnerberg P, Lou D, Hjerling-Leffler J, Haeggström J, Kharchenko O, Kharchenko PV, Linnarsson S, Ernfors P (2015) Unbiased classification of sensory neuron types by large-scale single-cell RNA sequencing. Nat Neurosci 18:145-153.

Viana F, de la Peña E, Belmonte C (2002) Specificity of cold thermotransduction is determined by differential ionic channel expression. Nat Neurosci 5:254-260.

Waxman SG, Kocsis JD, Black JA (1994) Type III sodium channel mRNA is expressed in embryonic but not adult spinal sensory neurons, and is reexpressed following axotomy. J Neurophysiol 72:466-470.

Wilson SR, Gerhold KA, Bifolck-Fisher A, Liu Q, Patel KN, Dong X, Bautista DM (2011) TRPA1 is required for histamine-independent, Mas-related G protein-coupled receptor-mediated itch. Nat Neurosci 14:595-602.

Xiao B, Dubin AE, Bursulaya B, Viswanath V, Jegla TJ, Patapoutian A (2008) Identification of transmembrane domain 5 as a critical molecular determinant of menthol sensitivity in mammalian TRPA1 channels. J Neurosci 28:9640-9651.

Yang Y, Mis MA, Estacion M, Dib-Hajj SD, Waxman SG (2018) NaV1.7 as a pharmacogenomic target for pain: moving toward precision medicine. Trends Pharmacol Sci 39:258-275.

Yu FH, Mantegazza M, Westenbroek RE, Robbins CA, Kalume F, Burton KA, Spain WJ, McKnight GS, Scheuer T, Catterall WA (2006) Reduced sodium current in GABAergic interneurons in a mouse model of severe myoclonic epilepsy in infancy. Nat Neurosci 9:1142-1149.

Yu Y, Shu Y, McCormick DA (2008) Cortical action potential backpropagation explains spike threshold variability and rapid-onset kinetics. J Neurosci 28:7260-7272.

Zimmermann K, Leffler A, Babes A, Cendan CM, Carr RW, Kobayashi J, Nau C, Wood JN, Reeh PW (2007) Sensory neuron sodium channel Nav1.8 is essential for pain at low temperatures. Nature 447:855-858. 